\title{
KAMILA KŁUDKIEWICZ
}

Uniwersytet im. Adama Mickiewicza w Poznaniu, Instytut Historii Sztuki

\section{Księgozbiór kolekcjonera dzieł sztuki. Słów kilka o bibliotece Seweryna hr. Mielżyńskiego z Miłosławia}

\begin{abstract}
Streszczenie. Seweryn hr. Mielżyński należał do grona najwybitniejszych kolekcjonerów dzieł sztuki w XIX-wiecznej Wielkopolsce. W pałacu w Miłosławiu posiadał liczący 5000 tomów księgozbiór, który w zapisie testamentowym przekazał bibliotece Towarzystwa Przyjaciół Nauk Poznańskiego. Na podstawie kwerendy i poszukiwań w dziś istniejącym księgozbiorze Biblioteki PTPN udało się odnaleźć 287 tytułów w 368 tomach, pochodzących z biblioteki miłosławskiej Seweryna Mielżyńskiego. Tematyka zachowanych książek wskazuje, że hrabia z Miłosławia oraz jego żona Franciszka zakupywali przede wszystkim współczesną literaturę piękną, a więc książki służące głównie rozrywce, zadumie, przyjemności. Ponadto dużą grupę tematyczną w zachowanym księgozbiorze miłosławskim stanowią prace z zakresu sztuki, architektury i fotografii, obrazujące zainteresowania artystyczne Seweryna Mielżyńskiego i przydatne $\mathrm{w}$ jego działalności malarza i fotografa amatora. Osobną grupą były książki z historiografii i historii sztuki, niezbędne w rozwoju kolekcjonerskiej pasji Mielżyńskiego i wykorzystane przez niego w opracowaniu katalogu kolekcji obrazów europejskiego malarstwa dawnego w Miłosławiu.
\end{abstract}

SŁowA KLuczowe: księgozbiór Seweryna hr. Mielżyńskiego, biblioteka w Miłosławiu, biblioteka kolekcjonera sztuki w XIX wieku, księgozbiory Mielżyńskich, polskie księgozbiory prywatne w XIX wieku.

Seweryn hr. Mielżyński (1804-1871) był jednym z najważniejszych kolekcjonerów dzieł sztuki w XIX-wiecznej Wielkopolsce ${ }^{1}$. Kolekcję dawnego malarstwa europejskiego konstruował przez kilkadziesiąt lat i prezentował ją w specjalnej galerii dobudowanej do pałacu w Miłosławiu. Przez

${ }^{1}$ Por. K. Kłudkiewicz, Wybór i konieczność. Kolekcje polskiej arystokracji w Wielkopolsce na przełomie XIX i XX wieku, praca doktorska napisana pod kierunkiem prof. dra hab. Tadeusza J. Żuchowskiego w Instytucie Historii Sztuki na Uniwersytecie im. Adama Mickiewicza w Poznaniu, Poznań 2013 (przygotowywana do druku), s. 80-104 (rozdz. Galeria Seweryna hr. Mielżyńskiego w Miłosławiu). 
całe życie zakupywał również książki, wzbogacając miłosławską bibliotekę o dzieła z zakresu historii, sztuki, polityki i literatury pięknej.

Seweryn był najmłodszym synem starosty Józefa hr. Mielżyńskiego (1765-1824) i Franciszki Niemojewskiej (1781-1861). Początkowo nad wykształceniem młodego hrabiego czuwał guwerner Jan Motty ${ }^{2}$. Następnie Seweryn uczył się w Collège Français i w gimnazjum w Berlinie $^{3}$, gdzie szczególnie intensywnie rozwijał swoją wiedzę $w$ zakresie nauk przyrodniczych, matematyki, rysunku i malarstwa. W wieku 18 lat udał się na studia przyrodnicze do Szwajcarii. Po powrocie do kraju, wraz z braćmi Maciejem (1799-1870) i Ignacym (1800-1831), wziął udział w walkach powstańczych na Litwie ${ }^{4}$. Udział w powstaniu listopadowym skutkował przymusową dziesięcioletnią emigracją po jego upadku. Mielżyński w tym czasie uczestniczył w wyprawie sabaudzkiej w 1834 roku ${ }^{5}$ i przystąpił do Towarzystwa Demokratycznego ${ }^{6}$. Po powrocie z emigracji w 1848 roku ożenił się z Franciszką z Wilkszyckich (1805-1874)7.

${ }^{2}$ Informacje biograficzne na podstawie: F. Skoraczewski, Materyaty do historyi Miłosławia, Poznań 1910, s. 376 i n. Filip Skoraczewski (1838-1910), z wykształcenia leśnik, w 1868 roku otrzymał posadę nadleśniczego w Miłosławiu od Seweryna Mielżyńskiego. W 1910 roku wydał książkę poświęconą Miłosławowi, w której jeden z rozdziałów dotyczy Mielżyńskich. Ze wstępu do wskazanej publikacji wynika, że „autor nie miał żadnej pretensji, żeby te materiały nazywać historią Miłosławia. Nie był on przecież historykiem z zawodu [...]. Nie korzystał n. p. wcale z nagromadzonych $\mathrm{w}$ archiwach poznańskich; ale przynajmniej te, które miał pod ręka, akta miłosławskie miejskie, cechowe, itd. wyczerpał należycie". Przytoczono te fragmenty książki Skoraczewskiego, które znajdują potwierdzenie również w innych źródłach.

${ }^{3}$ Taką informację podaje A. Wojtkowski, Historia Towarzystwa Przyjaciót Nauk w Poznaniu, Towarzystwo Przyjaciół Nauk w Poznaniu w latach 1857-1927, „Roczniki PTPN", t. 50, s. 281-286.

${ }^{4}$ W czasie wyprawy zginął pod Szawlami Ignacy hr. Mielżyński, a Seweryn został ranny pod Rajgrodem. F. Skoraczewski, op.cit., s. 379.

${ }^{5}$ Nieudana wyprawa gen. Girolamo Ramorina w marcu 1834 roku z inspiracji Giuseppego Mazziniego na Królestwo Sardynii. Por. P. Szlanta, Narodziny nowoczesnej Szwajcarii, „Mówią wieki” 2008, nr 5, s. 25-28. Mielżyński zaangażował się również w działalność emigracyjną w Szwajcarii - był jednym z głównych członków Komitetu Polskiego w Genewie. Por. korespondencję między Wincentym Gostkowskim a Sewerynem Gałęzowskim na ten temat. Archiwum Biblioteki Polskiej w Paryżu, sygn. akc. 2353.

${ }^{6}$ M. Tyrowicz, Towarzystwo Demokratyczne Polskie 1832-1863. Przywódcy i kadry członkowskie. Przewodnik biograficzny, Warszawa 1964, s. 433-434. Mielżyński podpisał listę członkostwa w Towarzystwie Demokratycznym Polskim 27 grudnia 1834 i 31 stycznia 1835 roku. Por. L. Krawiec, Lista członków Towarzystwa Demokratycznego Polskiego z lat 1832-1851, w: Materiaty do biografii, genealogii i heraldyki polskiej, t. 1, Buenos Aires-Paryż 1963, s. 58, poz. 985.

${ }^{7}$ Dopuszczalne dwie formy nazwiska panieńskiego żony Seweryna Mielżyńskiego: Wilxycka, Wilkszycka. Wilkszyccy byli rodem o korzeniach niemieckich 
W 1848 roku zaangażował się w działalność konspiracyjną i razem z Ludwikiem Mierosławskim zaczął organizować kolejne powstanie. Miłosław stał się areną bitwy 30 kwietnia 1848 roku. Pałac Mielżyńskich został wówczas zniszczony, a jego wyposażenie rozgrabione. Po 1848 roku Seweryn Mielżyński zajął się przede wszystkim odbudową pałacu i uzupełnianiem jego wyposażenia. Wraz z małżonką Franciszką stworzył w miłosławskim pałacu miejsce spotkań literatów, malarzy i muzyków ${ }^{8}$.

Il. 1. Seweryn hr. Mielżyński

Źródło: fotografia ze zbiorów Biblioteki Narodowej w Warszawie.

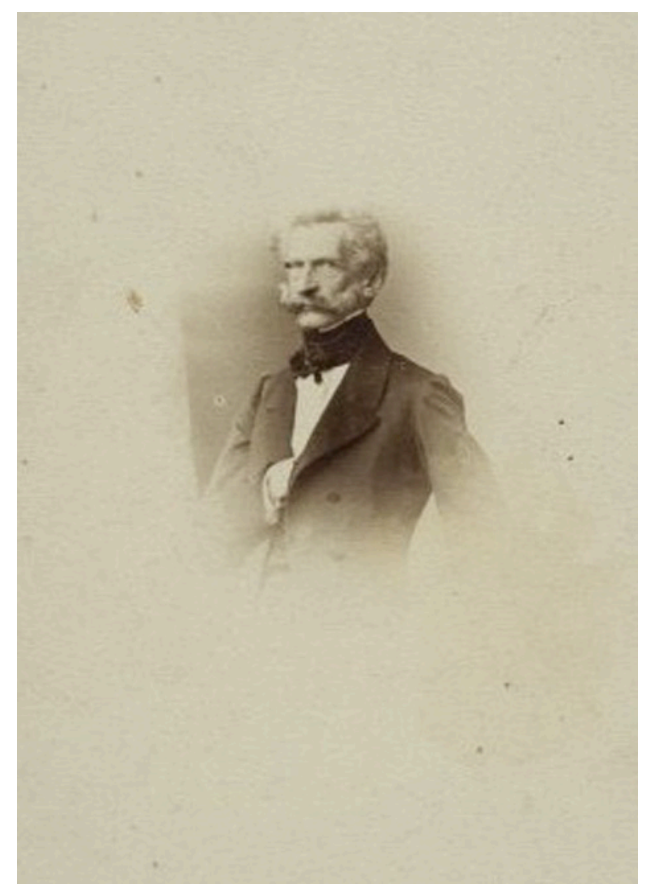

(pierwotnie Wildschütz), który osiadł w Prusach Królewskich. W drugiej połowie XVIII wieku Wilkszyccy zyskali na znaczeniu (a przede wszystkim wzbogacili się) i zakupili sporo dóbr na terenie Prus Królewskich (Wabcz w 1728 roku, Ryńsk, Ludowice, Orzechówko, Piotrowo w 1766 roku, Kamlarki w 1801 roku). Por. J. Krzepela, Rody ziem pruskich, Kraków 1927, s. 35, 52, 67, 73, 85, 105, 192. Franciszka Mielżyńska prowadziła przez całe życie korespondencję rodzinną. Udzielała się charytatywnie i wspomagała fundacje emigracyjne. Przez wiele lat opłacała działalność szkoły polskiej na Bartignolles (listy Franciszki Mielżyńskiej do sekretarza tej szkoły Seweryna Gałęzowskiego z lat 1854-1860, Biblioteka Polska w Paryżu, sygn. akc. 2353) i Biblioteki Polskiej w Paryżu (Archiwum Biblioteki Polskiej w Paryżu, sygn. BPP 1569, BPP 1572).

${ }^{8} \mathrm{O}$ atmosferze kulturalnej Miłosławia por. K. Kłudkiewicz, Prowincjonalne centra - o kolekcjach sztuki w siedzibach arystokratycznych w Wielkopolsce w drugiej połowie XIX wieku, w: Centrum, prowincje, peryferia. Wzajemne relacje w dziejach sztuki, red. P. Gryglewski, K. Stefański, R. Wróbel, Łódź 2013, s. 303-305. 


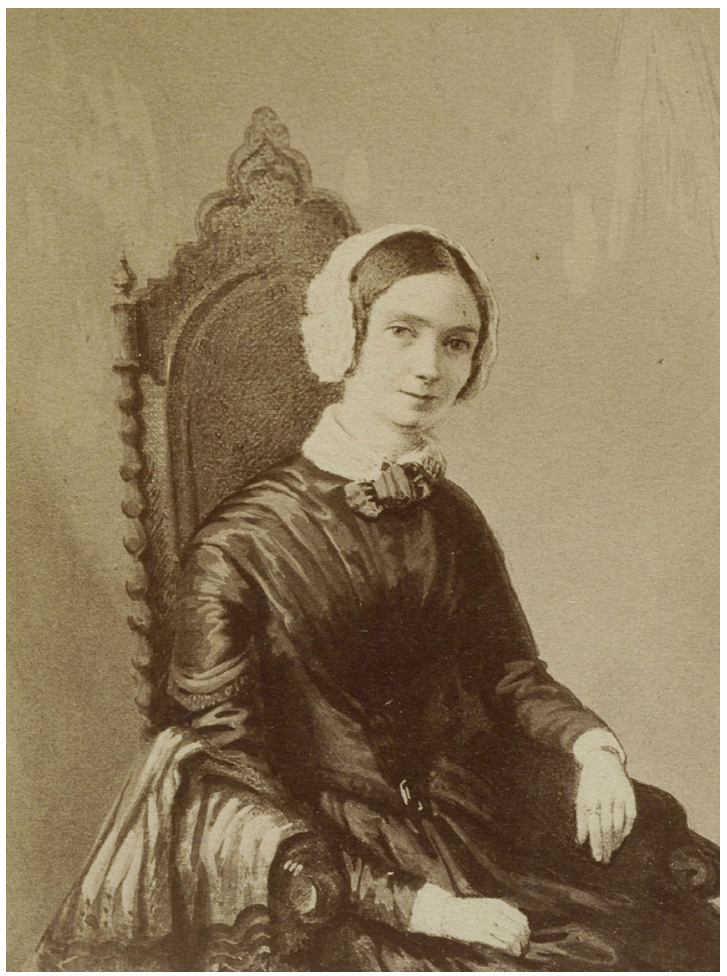

Il. 2. Franciszka z Wilkszyckich hr. Mielżyńska

Źródło: fotografia ze zbiorów Biblioteki Narodowej w Warszawie.

Małżonkowie wspierali działalność stowarzyszeń naukowych, w tym Poznańskiego Towarzystwa Przyjaciół Nauk (PTPN) ${ }^{9}$. Mielżyński zakupił działkę budowlaną, ufundował nową siedzibę i zdecydował się zapisać w spadku kolekcję obrazów i bibliotekę ${ }^{10}$. Na mocy testamentu i kodycylu małżonków Mielżyńskich zbiory przekazał Towarzystwu po śmierci Franciszki w 1874 roku jedyny spadkobierca hrabiostwa, bratanek Seweryna Mielżyńskiego, Józef hr. Mielżyński (1824-1900) z Iwna.

${ }^{9}$ Powstającemu w Towarzystwie muzeum Mielżyński ofiarował w latach 60 . XIX wieku dzieła sztuki, a na początku lat 70. finansował nabytki TPN-u. Ukoronowaniem donacji dla TPN-u był zakup kolekcji barona Edwarda Rastawieckiego, którą Mielżyński przekazał do zbiorów Towarzystwa. Por. A. Wojtkowski, op.cit., s. 281-286.

${ }^{10}$ Historię daru małżonków Mielżyńskich na rzecz PTPN-u przybliżają teksty: A. Jagielska-Burduk, W. Szafrański, M.A Górska, Wirtualna Galeria im. Mielżyńskich. Historia - idea - prawo, Poznań 2013, s. 16-26; K. Kłudkiewicz, Prywatne kolekcjonerstwo dzieł sztuki a kwestia ochrony dziedzictwa kulturowego - kiedyś $i$ dziś, w: Imponderabilia ochrony dziedzictwa kulturowego, red. S. Kowalska, Poznań-Kalisz 2015, s. $147-175$. 


\section{Stan badań}

O bibliotece Seweryna hr. Mielżyńskiego pisano dotąd niewiele. Wzmianki o księgozbiorze pojawiły się w tekstach historyków sztuki zajmujących się kolekcją malarstwa Mielżyńskiego. Dominika Cicha wymieniła kilka książek na temat grafiki, malarstwa, historii sztuki, które wchodziły w skład księgozbioru kolekcjonera ${ }^{11}$. Joanna Malinowska wskazała, że posiadał on również książki o architekturze i fotografii ${ }^{12}$.

Zamieszanie faktograficzne wkradło się już do pierwszych informacji poświęconych księgozbiorowi. W sprawozdaniu Towarzystwa Przyjaciół Nauk Poznańskiego (TPN) za rok 1882 wyróżniono dwa zbiory książek, które za sprawą Mielżyńskiego trafiły do TPN-u. Pierwszym był „znakomity zbiór książek i map", nabyty przez Mielżyńskiego razem z kolekcją malarstwa polskiego od barona Edwarda Rastawieckiego ${ }^{13}$. Drugim było „pięć tysięcy tomów z Miłosławia, między niemi jedyny może tak pełny zbiór dzieł i broszur w języku francuskim, niemieckim i angielskim, traktujących o Polsce, jej literaturze, historyi, szczególniej o wypadkach i katastrofach bieżącego wieku"14. Opisując historię Towarzystwa, w 1927 roku Andrzej Wojtkowski połączył te dwie informacje w jedną - zanotował, że składający się z 5000 tomów księgozbiór miłosławski Mielżyński nabył od Rastawieckiego ${ }^{15}$. Co prawda, Ludwika Dobrzyńska-Rybicka w 1929 roku sprostowała tę pomyłkę, wskazując, że sama biblioteka miłosławska liczyła 5000 tomów $^{16}$. Błędną informację za Wojtkowskim powtórzył jednak Ryszard Marciniak ${ }^{17}$.

${ }^{11}$ D. Cicha, Seweryn Mielżyński i jego kolekcja, w: Zbiory Poznańskiego Towarzystwa Przyjaciót Nauk w Muzeum Narodowym w Poznaniu (katalog wystawy), Poznań 1982, s. 26, 31.

12 J. Malinowska, Seweryn Mielżyński i jego galeria miłosławska, maszynopis, praca magisterska napisana pod kierunkiem prof. Krzysztofa Pomiana, Uniwersytet Mikołaja Kopernika, Wydział Nauk Historycznych, Katedra Sztuki i Kultury, Toruń, 2002, s. 13.

${ }^{13}$ Na temat zbiorów artystycznych Rastawieckiego por. A. Ryszkiewicz, Zastugi Edwarda Rastawieckiego jako kolekcjonera i mecenasa, w: Mecenas, kolekcjoner, odbiorca, Warszawa 1984, s. 147-164; K. Gieszczyńska-Nowacka, Kolekcjoner i artyści: Edward Rastawiecki wobec współczesnego środowiska artystycznego, w: Nowoczesność kolekcji, red. T.F. Rosset, A. Kluczewska-Wójcik, K. Lewandowska, Toruń 2010, s. 23-35.

14 Sprawozdanie z czynności Towarzystwa Przyjaciót Nauk Poznańskiego z roku 1882, „Roczniki Towarzystwa Przyjaciół Nauk Poznańskiego” 1882, t. 12, s. 56.

15 A. Wojtkowski, op.cit., s. 274.

${ }^{16}$ L. Dobrzyńska-Rybicka, Biblioteka Towarzystwa Przyjaciół Nauk, w: Biblioteki wielkopolskie i pomorskie, red. S. Wierczyński, Poznań 1929, s. 46.

${ }^{17}$ R. Marciniak, Zbiory biblioteczne Poznańskiego Towarzystwa Przyjaciót Nauk, w: Zbiory Poznańskiego Towarzystwa Przyjaciół Nauk w Muzeum Narodowym w Poznaniu (katalog wystawy), Poznań 1982, s. 33. 
Aby wyjaśnić kwestię dwóch księgozbiorów darowanych przez Mielżyńskiego TPN-owi, należy zaznaczyć, że biblioteka Rastawieckiego była znacznie większa od księgozbioru miłosławskiego. Jej nabycie zaś było związane z transakcją którą Mielżyński zawarł z baronem w 1870 roku. Zainteresowany pierwotnie wyłącznie obrazami z kolekcji Rastawieckiego Mielżyński został niejako zmuszony nabyć całość zbiorów kolekcjonera. Rastawiecki postawił bowiem warunek, że przedmiotem umowy mają być wszystkie zbierane przez niego dzieła: obrazy, szkice, ryciny, monety, medale i książki ${ }^{18}$. W zamian Rastawiecki zabiegał o dożywotnią pensję dla siebie, a po swojej śmierci - dla żony. Mielżyński przystał na warunki, gdyż planował część zbiorów Rastawieckiego spieniężyć.

Głównym celem, jaki przyświecał właścicielowi Miłosławia w czasie zakupu zbiorów Rastawieckiego, było przekazanie ich TPN-owi. Jak pisała Franciszka hr. Mielżyńska w liście do Józefa Ignacego Kraszewskiego, jej mąż ze zbiorów barona niewiele zatrzyma ${ }^{19}$ :

bibliotekę zaraz odda Towarzystwu Przyjaciół Nauk w Poznaniu, zapewniwszy ile się da od grabieży obcych. Ma ona być wielkiej wartości, katalogi ukazują dzieła, których już za żadną cenę nabyć nie można, powiada p. Żupański. Wszystkie zbiory systematycznie polskie, lub tyczące Polski [...]. Na bibliotekę [liczącą - K.K.] 14000 tomów wcale [w Miłosławiu - K.K.] miejsca nie ma.

Transport biblioteki Rastawieckiego do Poznania nie obył się bez utrudnień. Franciszka Mielżyńska w maju 1870 roku pisała:

trudniej z tem, co jest na wsi na Wołyniu ${ }^{20}$, tam prawie cała biblioteka i większa część obrazów, tam też po wyprawieniu z Warszawy pojedzie pan Ratykowski. Katalogi Seweryn ma ręką p. Rastawieckiego spisane, ale weryfikacja trudna bo część książek w pakach, tam musi być wszystko w nieporządku, bo nabywca dóbr chciał wszystko zaliczyć do rubryki meble, ale nipotent P. Cedrysz przewiózł więc wszystko do siebie to jest do dwóch wsi darowanych mu od tych dóbr przez p. Rastawieckiego ${ }^{21}$.

${ }^{18}$ Około 1870 roku Edward Rastawiecki poszukiwał instytucji, które przyjęłyby w darze jego różnorodne zbiory artystyczne i historyczne. W 1869 roku podarował kolekcję rzemiosła artystycznego Uniwersytetowi Jagiellońskiemu. Sytuacja życiowa zmusiła go jednak do sprzedaży i poszukiwania nabywcy dla pozostałych zbiorów.

${ }^{19}$ List Franciszki Mielżyńskiej do Józefa Ignacego Kraszewskiego z dnia 30.04.1870 r. z Miłosławia, Biblioteka Jagiellońska, 6521 IV, k. 156-157.

${ }^{20}$ Rastawiecki posiadał majątek ziemski i obszerny pałac w Dołhobyczowie.

${ }^{21}$ List Franciszki Mielżyńskiej do Józefa Ignacego Kraszewskiego z dnia 5.05.1870 r. z Miłosławia, Biblioteka Jagiellońska, 6521 IV, k. 159-160 
Ostatecznie we wrześniu 1870 roku księgozbiór dotarł do Poznania. Tymczasowa siedziba Towarzystwa i jego zbiorów mieściła się wówczas w Bazarze. Konserwator zbiorów TPN-u Hieronim Feldmanowski umieścił książki w sali na drugim piętrze Bazaru, jak pisała Franciszka Mielżyńska, „jedne na drugich" ${ }^{22}$, a więc dość prowizorycznie. Nie wiadomo jednak, ile dokładnie tomów przyjechało do Wielkopolski. Połączone one zostały z istniejącym zbiorem Towarzystwa, wciąż rozbudowywanym przez kolejne dary i włączane księgozbiory Wielkopolan. Na podstawie publikowanych w "Rocznikach Towarzystwa Przyjaciół Nauk Poznańskiego" sprawozdań można jedynie stwierdzić, że księgozbiór biblioteki Towarzystwa ponad trzykrotnie powiększył się po przyjęciu książek barona Rastawieckiego. W 1869 roku biblioteka PTPN-u liczyła 6602 tomy, na przełomie 1871 i 1872 roku 20000 tomów. Różnica w liczbie książek mniej więcej odpowiada wielkości księgozbioru Rastawieckiego (14 000 tomów $)^{23}$.

Poszukiwania śladów biblioteki Rastawieckiego w istniejącym dziś księgozbiorze PTPN-u uniemożliwia brak znaków własnościowych. Najwyraźniej książki Rastawieckiego nie zostały przez właściciela w żaden sposób oznakowane. W głównych opracowaniach na temat biblioteki TPN-u również próżno szukać choćby słowa na temat tak znacznego księgozbioru ${ }^{24}$, co dowodzi, że został on na przełomie 1870 i 1871 roku wchłonięty przez bibliotekę Towarzystwa i w ogóle niewyodrębniony pośród innych książek.

Podobnie trudno jest prześledzić losy trzykrotnie mniejszego księgozbioru Seweryna Mielżyńskiego. Po przekazaniu przez Józefa Mielżyńskiego książek z Miłosławia do TPN-u zostały one w 1873 roku włączone do biblioteki Towarzystwa, skatalogowane, w 1885 roku prawdopodobnie zinwentaryzowane ${ }^{25}$, ale nie były traktowane jako odrębny zespół. Tomy z Miłosławia trafiły do biblioteki w czasie, kiedy opiekował się

${ }^{22}$ List Franciszki Mielżyńskiej do Józefa Ignacego Kraszewskiego z dnia 2.10.1870 r., Biblioteka Jagiellońska, sygn. 6521 IV, k. 174-175.

${ }^{23}$ Por. Sprawozdania z czynności Towarzystwa Przyjaciót Nauk Poznańskiego od lipca 1866 do kwietnia 1869, „Roczniki Towarzystwa Przyjaciół Nauk Poznańskiego”, t. 5, s. 366; Sprawozdania z czynności Towarzystwa Przyjaciót Nauk Poznańskiego od kwietnia 1871 do grudnia 1872, „Roczniki Towarzystwa Przyjaciół Nauk Poznańskiego”, t. 7, s. 253.

${ }^{24}$ A. Wojtkowski, op.cit.; L. Dobrzyńska-Rybicka, op.cit.; A. Koehlerówna, Biblioteka Poznańskiego Towarzystwa Przyjaciót Nauk 1857-1957, „Roczniki Historyczne” 1957 , t. 23, s. 381-430.

25 Pierwszy inwentarz księgozbioru Towarzystwa powstał w 1885 roku. A. Koehlerówna, op.cit., s. 415. 
nią Hieronim Feldmanowski. Wprowadził on w księgozbiorze porządek „W grupach treściowych"26, a więc można podejrzewać, że bibliotekę Mielżyńskiego podzielono i rozstawiono na różnych półkach. Kolejny bibliotekarz Klemens Kantecki wprowadził w 1882 roku swój porządek książki numerował i ustawiał, uwzględniając tylko formaty ${ }^{27}$. W 1886 roku, kiedy opiekę nad zbiorem przejął Bolesław Erzepki, prawdopodobnie wszystkie egzemplarze po raz kolejny zdjęto $\mathrm{z}$ regałów i ułożono $\mathrm{w}$ nowym, opracowanym przez następnego bibliotekarza porządku ${ }^{28}$.

Ponieważ księgozbiór Seweryna Mielżyńskiego nie miał specjalnego statusu w bibliotece TPN-u, bardzo prawdopodobne jest, że część tytułów została wciągnięta do katalogu dubletów i sprzedana ${ }^{29}$. Ponadto książki z Miłosławia, jak i cały księgozbiór biblioteki PTPN-u zostały mocno zniszczone w czasie II wojny światowej ${ }^{30}$.

\section{Ogólna charakterystyka księgozbioru Seweryna Mielżyńskiego}

Na podstawie inwentarzy proweniencji, prowadzonych i uzupełnianych przez pracowników Biblioteki Poznańskiego Towarzystwa Przyjaciół Nauk ${ }^{31}$, kwerendy w księgach inwentarzowych tej biblioteki oraz moich własnych poszukiwań w księgozbiorze PTPN-u udało mi się odnaleźć 287 tytułów w 368 tomach, pochodzących z biblioteki miłosławskiej Seweryna Mielżyńskiego. Zakładając, że księgozbiór miłosławski składał się z 5000 woluminów, odnaleziono jedynie 5,74\% całego zbioru. Analiza zachowanych w bibliotece PTPN-u tytułów pozwala jednak na wysunięcie kilku wniosków odnośnie do zainteresowań kolekcjonera z Miłosławia.

${ }^{26}$ A. Koehlerówna, op.cit., s. 405.

${ }^{27}$ L. Dobrzyńska-Rybicka, op.cit., s. 53.

28 A. Koehlerówna, op.cit., s. 407.

${ }^{29}$ Księgozbiór TPN-u powiększał się przede wszystkim dzięki darom, co skutkowało dużą liczbą dubletów. Pierwszy katalog dubletów powstał w 1872 roku, kolejne w 1883, 1891, 1897 roku. Ponadto biblioteka wymieniała książki z innymi książnicami na ziemiach polskich i za granicą. Inaczej niż w przypadku innych znacznych księgozbiorów podarowanych Towarzystwu (np. ks. Jana Koźmiana) dar Mielżyńskiego nie był obwarowany zakazem sprzedaży książek.

${ }^{30}$ Por. R. Marciniak, op.cit., s. 35-36.

${ }^{31} \mathrm{~W}$ tym miejscu serdecznie dziękuję za pomoc Pani Joannie Pietrowicz i Pani Anecie Piechockiej-Sterczale z Biblioteki Poznańskiego Towarzystwa Przyjaciół Nauk. 
Książki z Miłosławia w większości opatrzone są na stronach tytułowych autografem Seweryna Mielżyńskiego (il. 3-4) lub jego żony Franciszki (il. 5-6). Na niektórych egzemplarzach obok podpisu właściciela zachowała się również pieczęć, prawdopodobnie z herbem Nowina Mielżyńskich (il. 7). Właściciel Miłosławia stosował też dwie pieczątki - jedną z inicjałami SM (il. 8), drugą z podpisem „SMielżyński” (il. 9).

Jedna książka z biblioteki miłosławskiej posiada autograf innej osoby. Na stronie tytułowej Traité de perspective théorique et pratique Lamberta Salme'a ${ }^{32}$ znajduje się podpis Leona Kaplińskiego (il. 10). Malarz i poeta

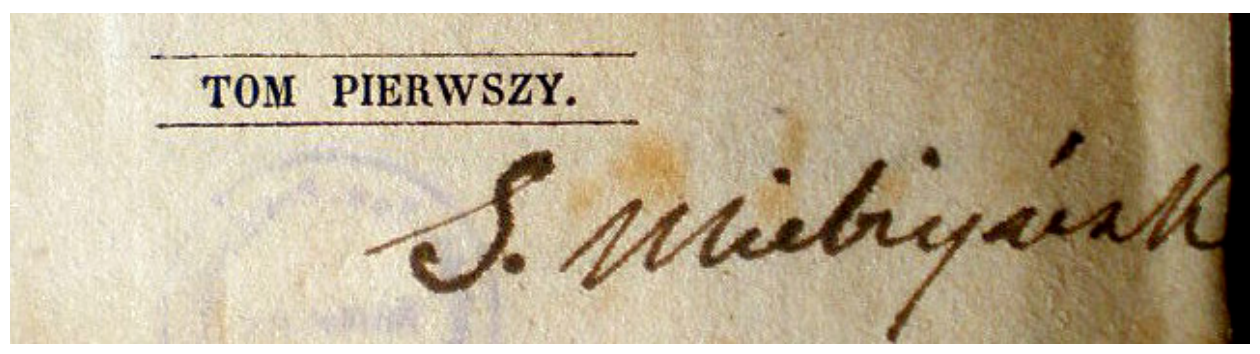

Il. 3. Autograf Seweryna Mielżyńskiego na stronie tytułowej Tłómaczeń Antoniego Edwarda Odyńca

Źródło: Biblioteka Poznańskiego Towarzystwa Przyjaciół Nauk. Fot. Kamila Kłudkiewicz.

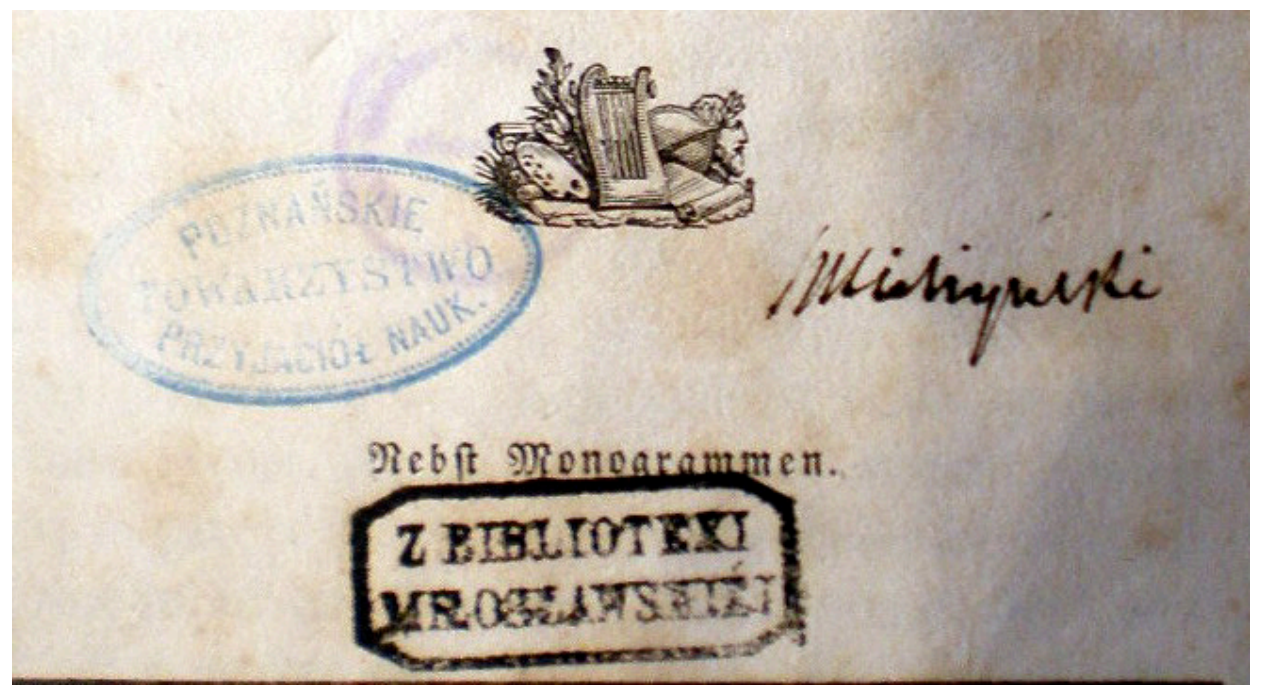

Il. 4. Autograf Seweryna Mielżyńskiego na stronie tytułowej Neues Maler-Lexikon zum Handgebrauch für Kunstfreunde

Źródło: Biblioteka Poznańskiego Towarzystwa Przyjaciół Nauk. Fot. Kamila Kłudkiewicz.

${ }^{32}$ L. Salme, Traité de perspective théorique et pratique, Paris 1843. 


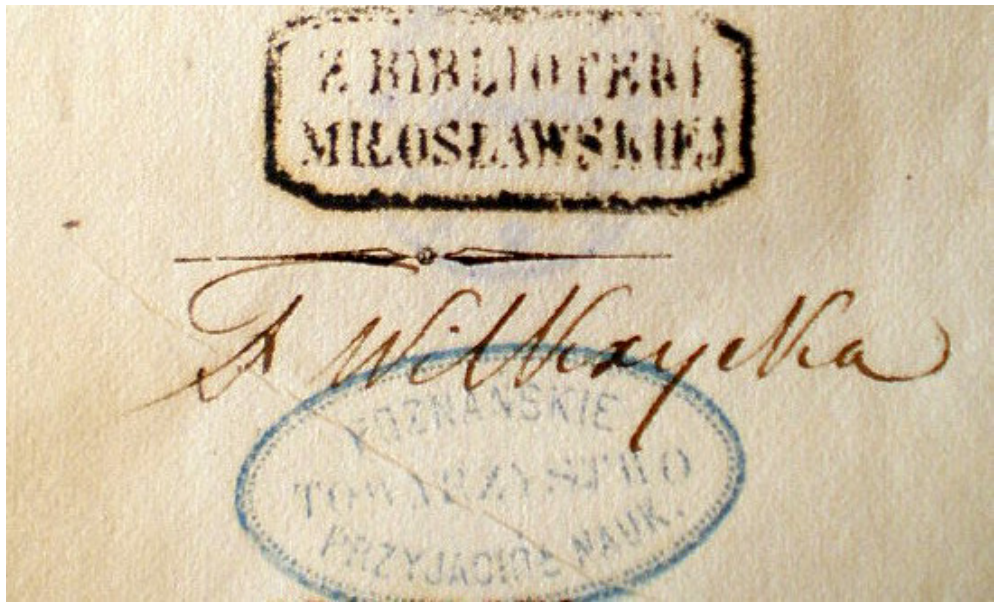

Il. 5. Autograf Franciszki Wilkxyckiej na stronie tytułowej Souvenirs et Mémoires de Madame Comtesse Merlin

Źródło: Biblioteka Poznańskiego Towarzystwa Przyjaciół Nauk. Fot. Kamila Kłudkiewicz.

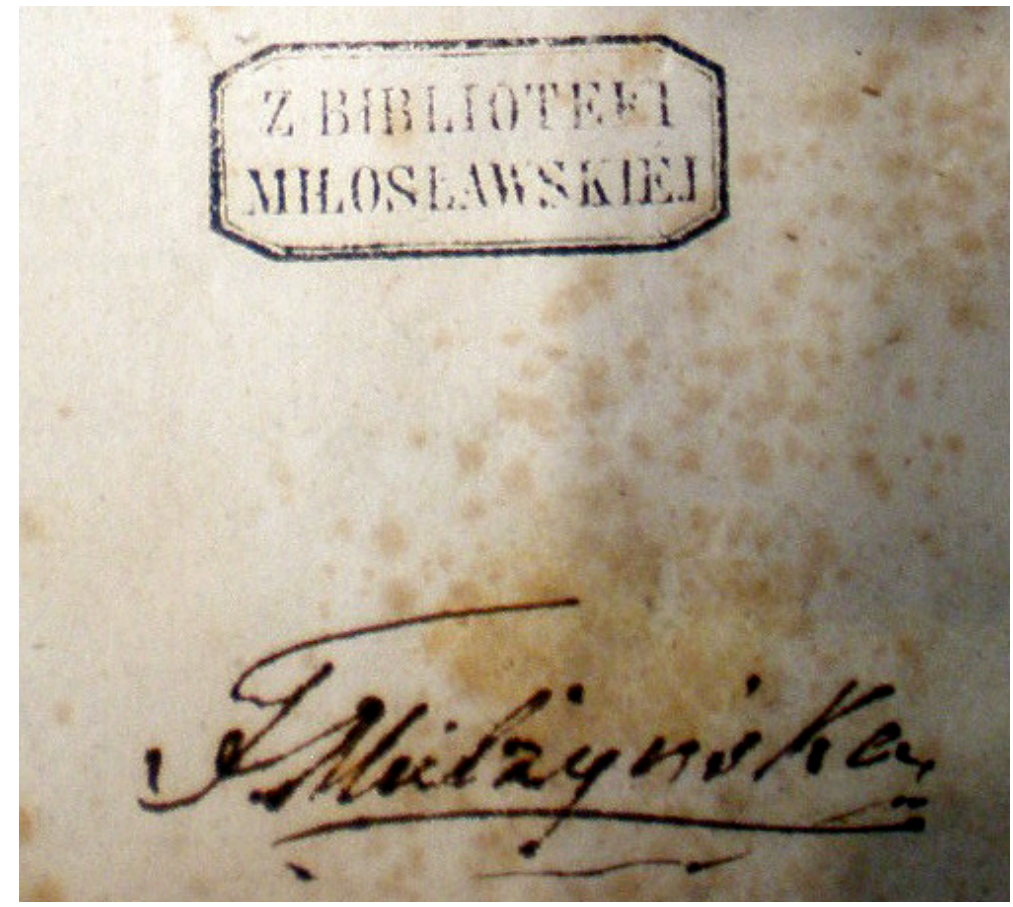

Il. 6. Autograf Franciszki Mielżyńskiej na stronie tytułowej książki La Divina Comedia

Źródło: Biblioteka Poznańskiego Towarzystwa Przyjaciół Nauk. Fot. Kamila Kłudkiewicz. 


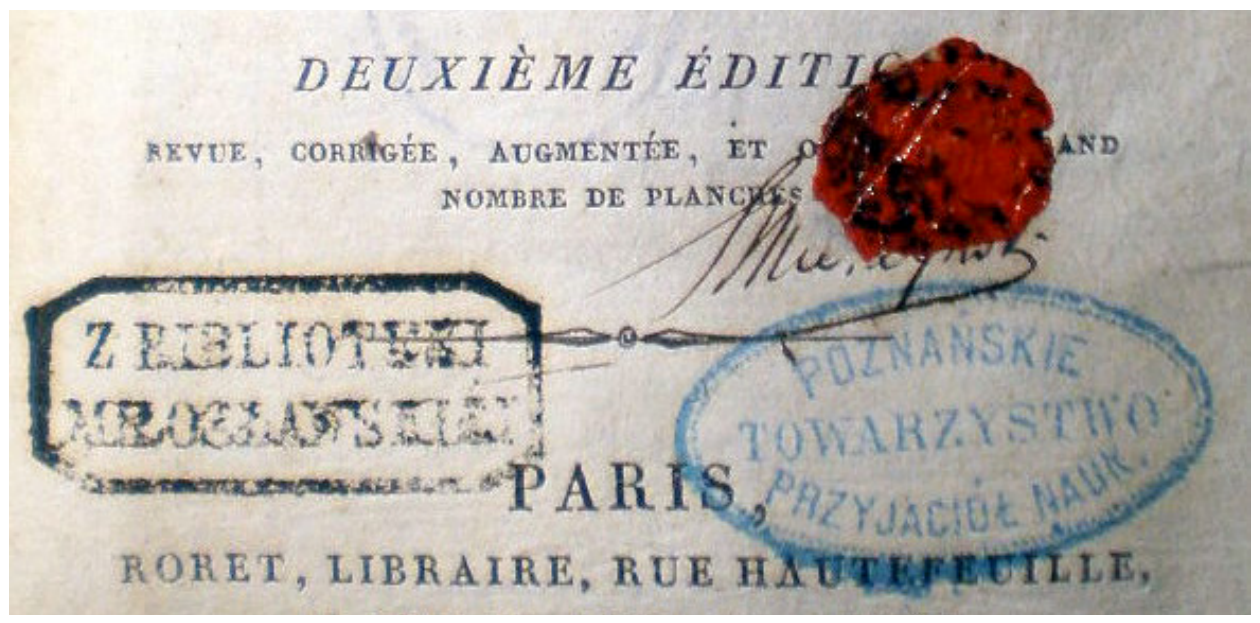

Il. 7. Pieczęć herbu Nowina Mielżyńskich na stronie tytułowej Manuel de perspective, $d u$ dessinateur et $d u$ peintre

Źródło: Biblioteka Poznańskiego Towarzystwa Przyjaciół Nauk. Fot. Kamila Kłudkiewicz.

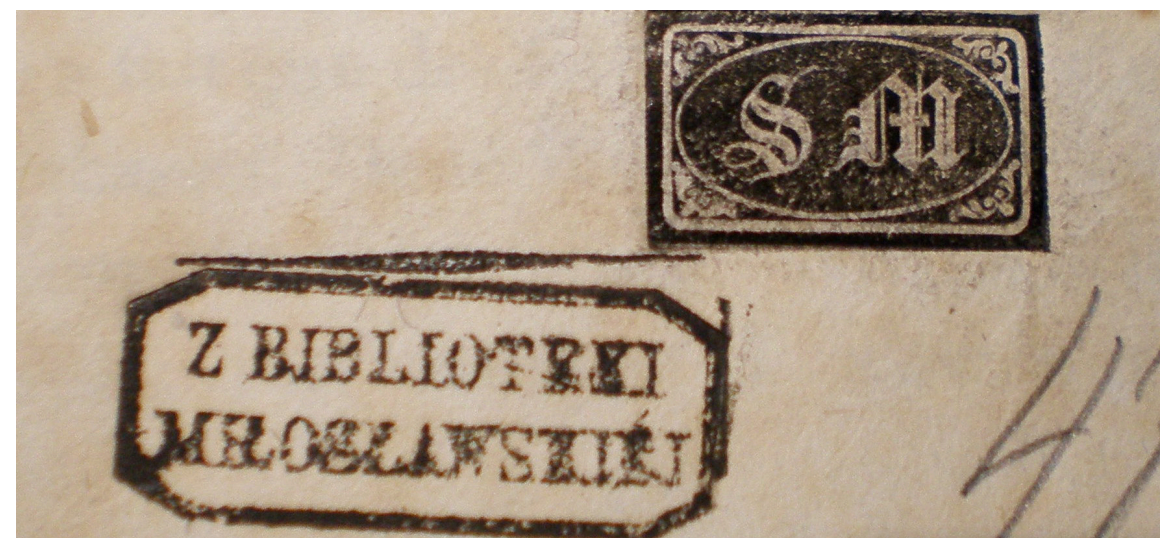

Il. 8. Pieczątka z inicjałami Seweryna Mielżyńskiego na stronie tytułowej tomu 11 „Notices sur les graveurs”

Źródło: Biblioteka Poznańskiego Towarzystwa Przyjaciół Nauk. Fot. Kamila Kłudkiewicz.

przyjaźnił się z Sewerynem Mielżyńskim od lat 40. XIX wieku do śmierci kolekcjonera. Kapliński wielokrotnie odwiedzał Miłosław, a pod koniec życia, latem 1872 roku przeniósł się na stałe do hrabiostwa Mielżyńskich. W pałacu miłosławskim dysponował mieszkaniem i atelier. Tam też zmarł w 1873 roku i został pochowany w krypcie grobowej Mielżyńskich ${ }^{33}$. Jego s. 28.

${ }^{33}$ Por. Ł. Krzywka, Sztuk-mistrz polski Leon Kapliński (1826-1873), Wrocław 1994, 


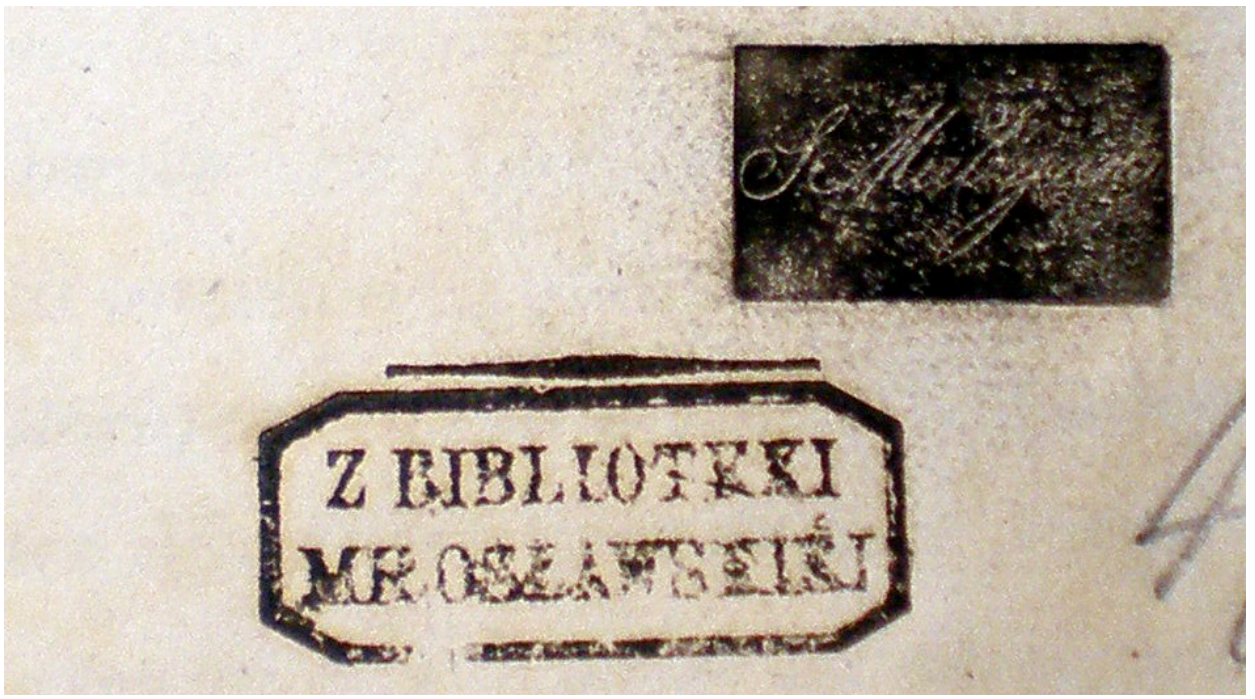

Il. 9. Pieczątka Seweryna Mielżyńskiego na stronie tytułowej tomu 1 „Notices sur les graveurs"

Źródło: Biblioteka Poznańskiego Towarzystwa Przyjaciół Nauk. Fot. Kamila Kłudkiewicz.

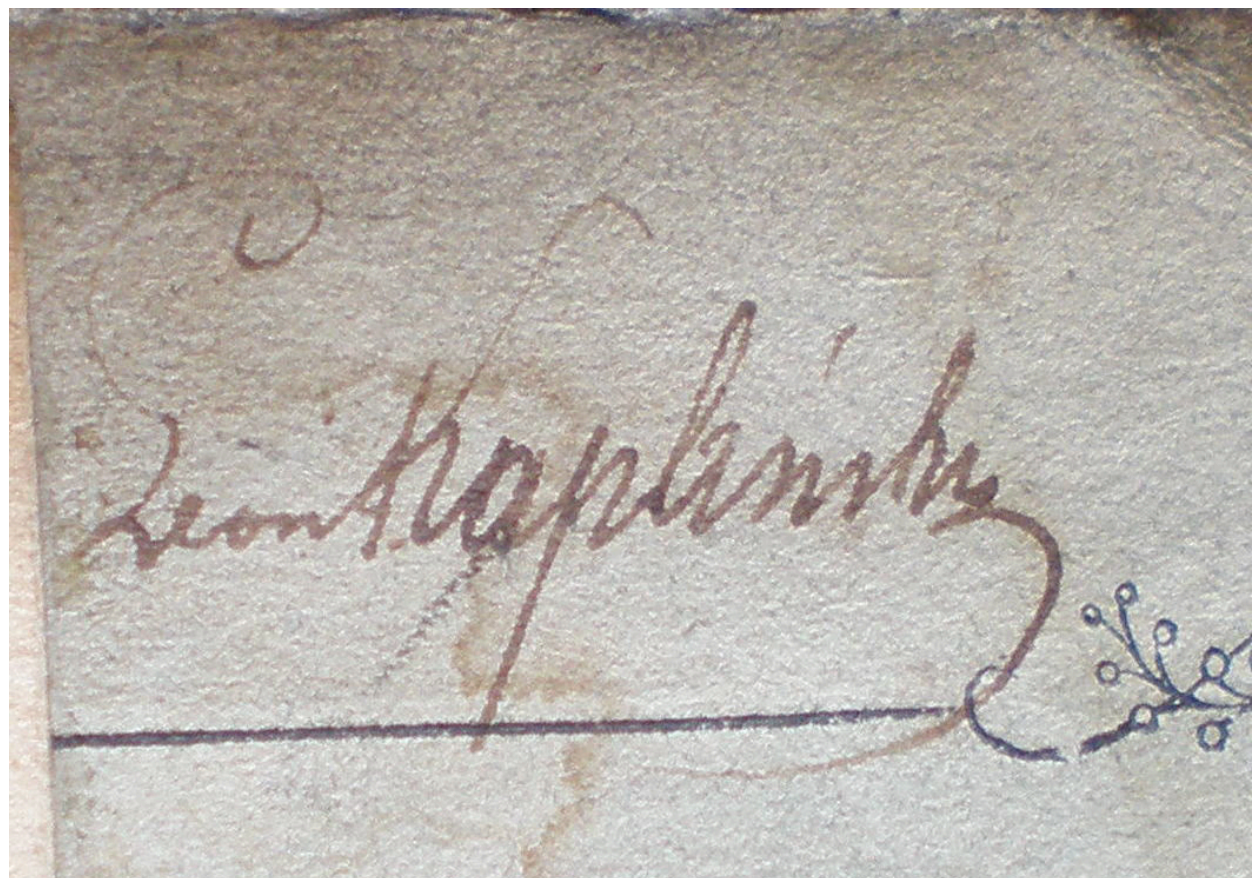

Il. 10. Autograf Leona Kaplińskiego na stronie tytułowej Traité de perspective théorique et pratique

Źródło: Biblioteka Poznańskiego Towarzystwa Przyjaciół Nauk. Fot. Kamila Kłudkiewicz. 
rzeczy po śmierci zostały najprawdopodobniej w pałacu, zaś omawiany tom wdowa po Sewerynie Franciszka Mielżyńska włączyła do księgozbioru miłosławskiego.

Książki pochodzące z Miłosławia pracownicy biblioteki PTPN-u prawdopodobnie w latach 20. XX wieku oznaczyli dodatkowo pieczątką z napisem „Z BIBLIOTEKI MIŁOSŁAWSKIEJ” lub „Z KSIĘGOZBIORU MIŁOSŁAWSKIEGO”. Zważywszy na opisane wyżej, dość niepewne losy książek Mielżyńskiego po włączeniu ich do księgozbioru Towarzystwa, trudno dziś ocenić, na jakiej podstawie znakowano woluminy. Nie wiadomo, czy istniał wówczas spis książek przejętych od spadkobierców Mielżyńskich, czy część książek z Miłosławia była przechowywana oddzielnie, w jednym miejscu. Nie wszystkie woluminy opatrzone wskazaną pieczęcią mają autograf Mielżyńskich. Niemniej jednak w niniejszym tekście przyjęto, że owo oznaczenie wskazuje na faktyczne pochodzenie książek z Miłosławia.

Kilka woluminów nosi ślady wędrówki pomiędzy różnymi księgozbiorami Mielżyńskich. Na stronie tytułowej Anfangsgründe der Artillerie Karla Augusta Stuensee z 1769 roku $^{34}$ znajduje się obok podpisu Mielżyńskiego pieczątka: „Biblioteka Iwieńska”. Możliwe, że sam Seweryn Mielżyński podarował książkę bratu Maciejowi (1799-1870) lub bratankowi Józefowi, właścicielom Iwna. Być może trafiła ona dopiero po śmierci kolekcjonera do księgozbioru tej linii Mielżyńskich ${ }^{35}$, skąd wraz z innymi woluminami z tej biblioteki przewieziono ją po 1945 roku do PTPN-u.

Niektóre książki mają na stronie tytułowej dedykacje autorów dla Seweryna Mielżyńskiego, świadczące o znajomościach i bliskich kontaktach właściciela Miłosławia z pisarzami. Julian Łukaszewski $(1835-1906)^{36}$, wielkopolski lekarz i działacz społeczny, który dzięki finansowemu wsparciu Seweryna Mielżyńskiego studiował w Niemczech medycynę, wpisał odręczną dedykację dla małżonków Mielżyńskich w książce Zabór Pruski w czasie Powstania Styczniowego 1863-64 (il. 11). Z kolei Józef Ignacy Kraszewski, zaprzyjaźniony z małżonkami Mielżyńskimi, oficjalnie zadedykował im swoje opowiadania wydane w tomie Tułacze.

Szczególnie interesująco prezentuje się dedykacja Louisa Alberta Neckera (1786-1861), genewskiego geologa, mineraloga i ornitologa, związa-

${ }^{34}$ K.A. Stuensee [von Karlsbach], Anfangsgründe der Artillerie, Leipzig-Liegnitz 1769.

${ }^{35}$ Nie można wykluczyć, że po śmierci Franciszki Mielżyńskiej, zanim Józef Mielżyński przekazał bibliotekę TPN-owi, kilka książek z Miłosławia trafiło do Iwna.

${ }^{36}$ S. Kieniewicz, Łukaszewski Julian, w: Polski słownik biograficzny, t. 18, Kraków 1973, s. 551-552. 


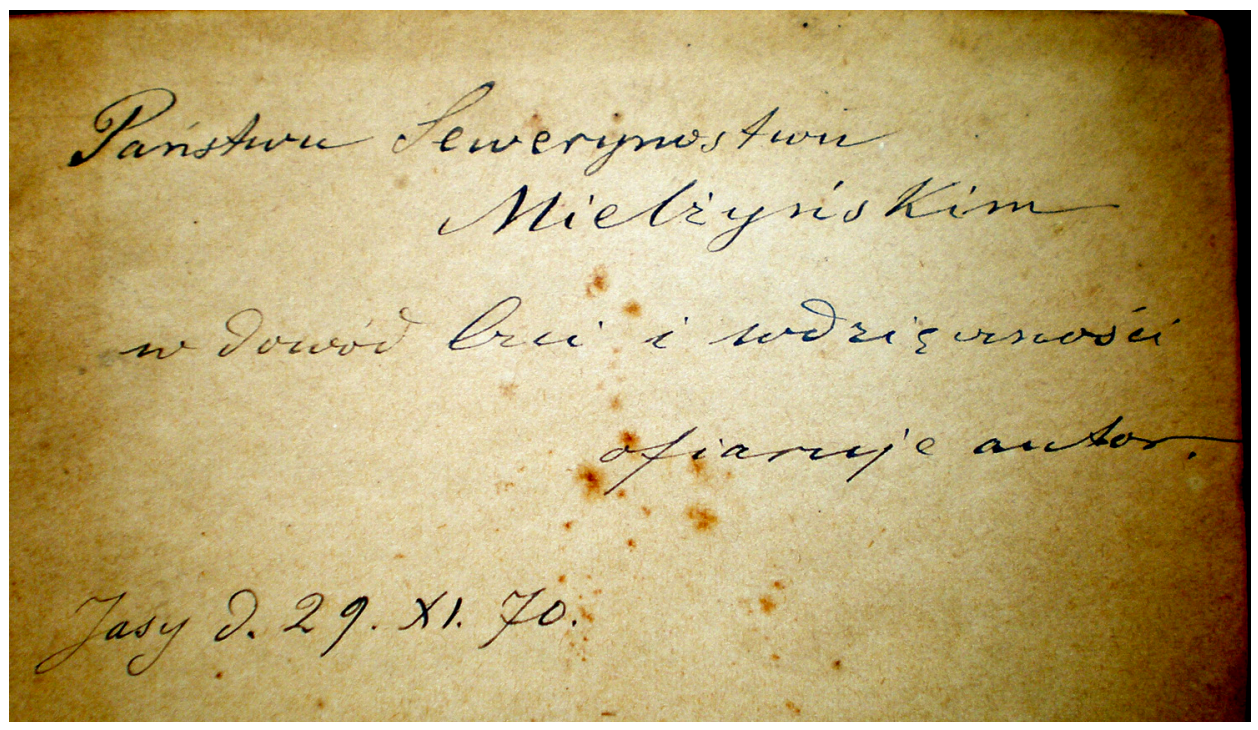

Il. 11. Dedykacja Juliana Łukaszewskiego na pierwszej stronie książki Zabór Pruski w czasie Powstania Styczniowego 1863-64

Źródło: Biblioteka Poznańskiego Towarzystwa Przyjaciół Nauk. Fot. Kamila Kłudkiewicz.

nego z Akademią Genewską ${ }^{37}$. Na pierwszej stronie swojej publikacji zatytułowanej Mémoire sur les oiseaux des environs de Genève, będącej zapisem referatu wygłoszonego na posiedzeniu Société de Physique et d'Histoire naturelle de Genève, napisał: „ $\mathrm{M}^{\mathrm{r}}$ le Comte Mielzinski de la part de l'auteur" (il. 12). Dedykacja wiąże się z pobytami Seweryna Mielżyńskiego w Genewie. Po raz pierwszy młody hrabia wyjechał do tego miasta w wieku 18 lat, aby dokończyć edukację gimnazjalną ${ }^{38}$, zdać maturę i rozpoczać studia przyrodnicze. Wiadomo, że w czasie studiów dzięki zainteresowaniu geologią i petrografią zgromadził swój pierwszy zbiór - kolekcję minerałów ${ }^{39}$. W związku z tymi zamiłowaniami młody Mielżyński mógł

37 Por. wspomnienie o Neckerze: A. de Candolle, Rapport sur les travaux de la Société, „Mémoires de la Société de physique et d'histoire naturelle de Genève" 1862, t. 16, s. $452-456$.

${ }^{38}$ Mielżyński początkowo uczył się w Collège Français i w gimnazjum w Berlinie (taką informację podaje A. Wojtkowski, op.cit., s. 281-286). Zdanie matury w Genewie potwierdza list prof. J.J. Schauba (Professeur Secrétaire de la Faculté des Sciences) z dnia 12 sierpnia 1823 roku, w którym gratuluje on Sewerynowi uzyskania stopnia Bachelier aux Sciences, Archiwum Państwowe w Poznaniu, Zespół Dokumenty i akta osób i rodzin, sygn. 157/1.

${ }^{39}$ Skoraczewski podał, że Mielżyński darował kolekcję poznańskiemu gimnazjum (F. Skoraczewski, op.cit., s. 376). Potwierdził to również M. Motty (Przechadzki po mieście, t. 1, oprac. Z. Grot, Poznań 1999, s. 99). 
nawiązać kontakty z Neckerem i uczestniczyć w roli słuchacza w wykładach genewskiego geologa. Bardziej prawdopodobne jest jednak, że swoją książkę Necker zadedykował nie Sewerynowi, ale jego starszemu bratu - Ignacemu hr. Mielżyńskiemu. Podobnie jak Seweryn, starszy od niego o cztery lata Ignacy studiował w Genewie i angażował się w życie kulturalne i naukowe miasta. W 1822 roku wygłosił na posiedzeniu Société de phisique et d'histoire naturelle de Genève referat zatytułowany Mémoire sur les Mollusques Gastéropodes ${ }^{40}$. Ignacy zginął w walce w czasie powstania listopadowego i być może Seweryn przechowywał książkę ze studenckich, genewskich czasów jako pamiątkę po starszym bracie.

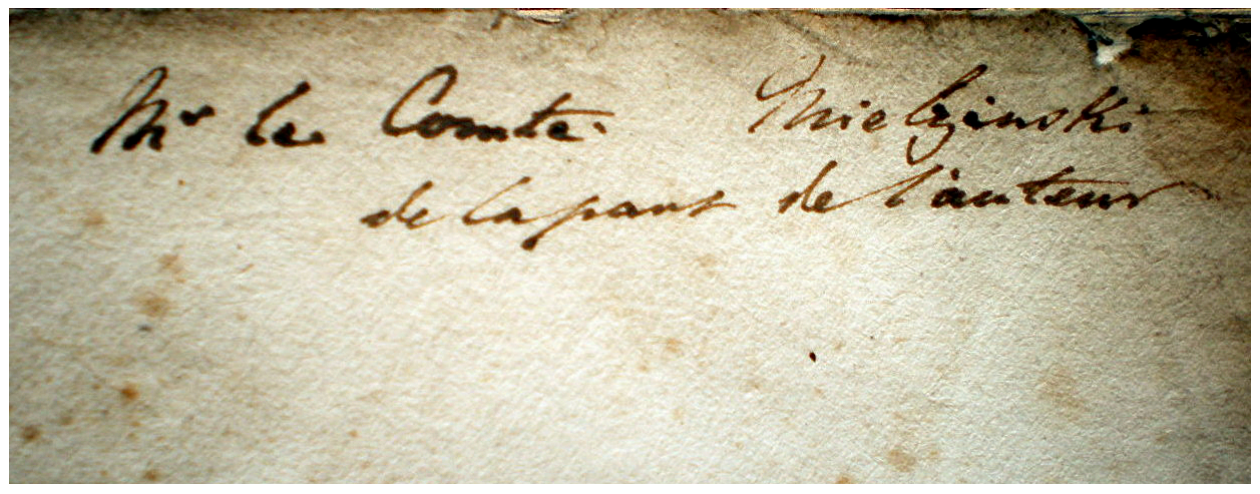

Il. 12. Dedykacja Louisa Alberta Neckera w jego książce Mémoire sur les oiseaux des environs de Genève

Źródło: Biblioteka Poznańskiego Towarzystwa Przyjaciół Nauk. Fot. Kamila Kłudkiewicz.

Zachowane książki pochodzą w zdecydowanej większości z XIX wieku, kilka obiektów to wydania z XVIII stulecia, pojedyncze woluminy z XVI i XVII wieku. Dowodzi to, że Seweryn Mielżyński kupował przede wszystkim książki współczesne, zaś kilka starszych tomów, które nabył, wiązało się z jego zainteresowaniami, o czym więcej poniżej. Księgozbiór odzwierciedlał bowiem pasje Mielżyńskiego, rozwijane w ciągu całego życia, oraz dość dobrą orientację w nowościach wydawniczych $\mathrm{z}$ różnych dziedzin, pojawiających się na rynku księgarskim od lat 20. do lat 70. XIX wieku.

Tematyka zachowanych książek z biblioteki miłosławskiej (tab. 1, wykres 1) wskazuje, że Seweryn Mielżyński oraz jego żona Franciszka kupowali przede wszystkim współczesną literaturę piękną, a więc publikacje służące głównie rozrywce, zadumie, przyjemności.

${ }^{40}$ Brudnopis i wersja ostateczna referatu o ślimakach (mięczakach) znajdują się w Bibliotece Kórnickiej (BK, sygn. 11272/3). 
Tabela 1. Tematyka książek z księgozbioru miłosławskiego

\begin{tabular}{|l|c|}
\hline \multicolumn{1}{|c|}{ Tematyka książek } & Liczba tytułów \\
\hline Literatura piękna & 24 \\
\hline Architektura i inżynieria, w tym: & 18 \\
\hline - architektura & 59 \\
\hline - inżynieria - konstrukcja mostów & 6 \\
\hline Sztuka, w tym: & 32 \\
\hline - emalierstwo i szkło & 7 \\
\hline - historia sztuki & 10 \\
\hline - grafika & 4 \\
\hline - katalogi zbiorów i wystaw & 9 \\
\hline - podręczniki rysunku i malarstwa & 33 \\
\hline Fotografia & 8 \\
\hline Historia i wojskowość, w tym: & 25 \\
\hline - wojskowość & 20 \\
\hline - historia & 6 \\
\hline Polityka współczesna & 2 \\
\hline Czasopisma & 3 \\
\hline Encyklopedie, słowniki & 287 \\
\hline Inne & \\
\hline Razem & 24 \\
\hline
\end{tabular}

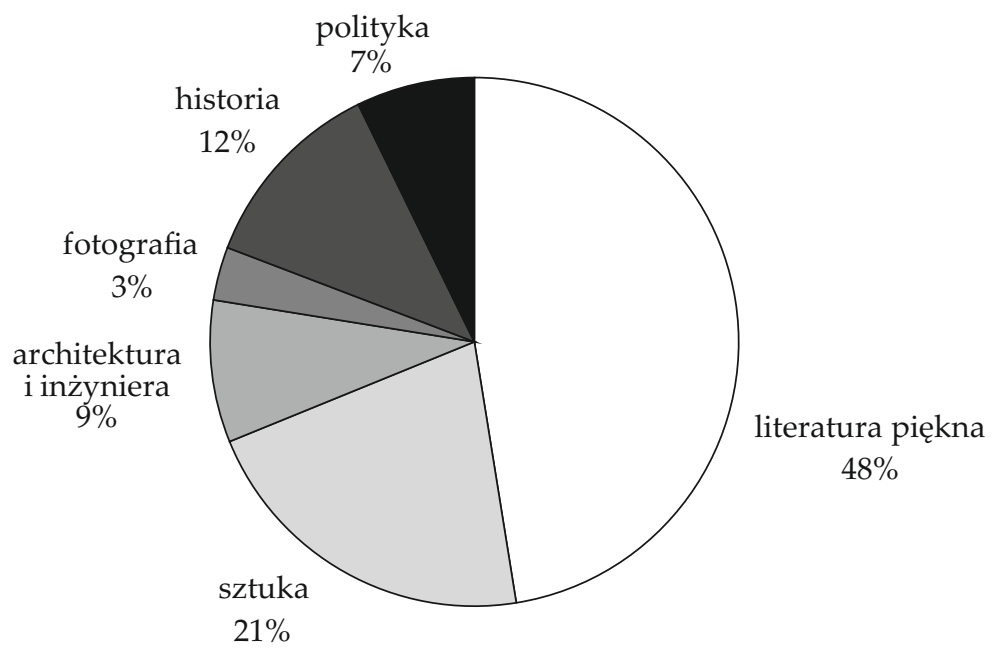

Wykres 1. Tematyka książek z księgozbioru miłosławskiego 
W Miłosławiu znajdowały się książki polskich pisarzy współczesnych (Juliusza Słowackiego ${ }^{41}$, Stefana Garczyńskiego ${ }^{42}$, Wincentego Pola ${ }^{43}$, Józefa Ignacego Kraszewskiego ${ }^{44}$, Teofila Lenartowicza ${ }^{45}$, Aleksandra Fredry ${ }^{46}$, Stanisława Syrokomli ${ }^{47}$ ), dzieła dawnych (Jeana Baptiste'a Racine'a ${ }^{48}$, Woltera $^{49}$, Moliera ${ }^{50}$ ) i współczesnych Francuzów (Victora Hugo ${ }^{51}$, Theophile'a Gautiera $^{52}$, braci Edmonda i Julesa Goncourtów ${ }^{53}$, Alexandre'a Dumasa syna $^{54}$ ), różne wydania dzieł Szekspira ${ }^{55}$, a także książki Waltera Scotta ${ }^{56}$ czy George’a Byrona ${ }^{57}$. W dwóch książkach znajduje się podpis Franciszki Mielżyńskiej - na stronie tytułowej Souvenirs et Mémoires de Madame la Comtesse Merlin ${ }^{58}$ Franciszka podpisała się nazwiskiem panieńskim

${ }^{41}$ J. Słowacki, Xiażę Niezłomny (z Calderona de la Barca), Paryż 1844; idem, Sen srebrny Salomei. Romans dramatyczny w pięciu aktach, Paryż 1844; idem, Jan Bielecki. Poemat, Petersbourg 1857.

42 S. Garczyński, Poezye, Lipsk 1860.

${ }^{43}$ W. Pol, Drobne Poezye, Kraków 1856; idem, Powódź. Dramat w trzech aktach, Poznań 1868; idem, Pieśń o domu naszym, Lwów 1866; idem, Stryjanka. Tradycja szlachecka, Warszawa 1861; idem, Kilka kart z krwawego rocznika, Lipsk 1864.

44 Tułacze. Opowiadania historyczne przez B. Bolesławite, Poznań 1868; Omnibus, przez B. Bolesławite, Poznań 1869; J.I. Kraszewski, Mogilna. Obrazek wspótczesny, Warszawa 1871; idem, Kopciuszek. Powieść, t. 3, 5, Wilno 1863; idem, Wspomnienia Polesia, Wołynia i Litwy, Paryż [s.a.]; idem, Pod włoskiem niebem, Lwów 1872; idem, Ostrożnie z ogniem, Lwów 1872; idem, Podróż do miasteczka. Powieść, Warszawa 1857; idem, Zagadki. Obrazy wspótczesne, t. 1-2, Poznań 1870.

45 T. Lenartowicz, Ze starych Zbroic. Rytmy Teofila Lenartowicza, Lwów 1870.

${ }^{46}$ A. Fredro, Komedye Jana Alexandra hrabiego Fredry, t. 1, Warszawa 1870; idem, Komedye, t. 1-2, Warszawa 1871.

47 S. Syrokomla, Poezye, Warszawa 1862.

48 J. Racine, Oeuvres..., t. 1, 3, Amsterdam-Leipzig 1750.

${ }^{49}$ Voltaire, Brutus. Tragédie, [s.1.] 1772.

50 Sainte-Beuve [Charles Augustin], Ouevres de Moliere, précédées d'une notice sur sa vie et ses ouvrages, t. 1-2, Paris 1835-1836.

${ }^{51}$ V. Hugo, Oeuvres completes de Victor Hugo, t. 1-2, Paris 1843; idem, L'année terrible, Paris 1872; idem, L'homme qui Rit, t. 1-3, Paris 1869.

52 Th. Gautier, Tableaux de siège, Paris 1870-1871.

${ }^{53}$ E. Goncourt, J. Goncourt, La femme au dix-huitième siècle, Paris 1862.

54 A. Dumas syn, L'homme-femme. Réponse à Henri d'Ideville, Paris 1872.

55 The Works of Shakespeare, London 1825; Shakespeare, The pictorial edition of..., London 1838.

${ }^{56}$ W. Scott, The poetics works, Paris 1827.

57 G.G. Byron, Mazepa. Poemat..., Paryż 1860; idem, Manfred. Poemat..., Paryż 1860.

58 [Maria de las Mercedes de Jesuco de], Souvenirs et Mémoires de Madame la Comtesse Merlin, t. 2, Bruxelles-Leipzig 1837. 
„Wilkxycka” (il. 5), w La Divina Commedia di Dante Alighieri - już jako żona Mielżyńskiego (il. 6) ${ }^{59}$.

W Miłosławiu znajdowały się również dzieła historyczne (dotyczące historii różnych państw europejskich ${ }^{60}$ i wojskowości ${ }^{61}$ ) oraz współczesne wydawnictwa polityczne, komentujące aktualną sytuację na ziemiach polskich i w Europie. Tych ostatnich nie udało się dziś odnaleźć zbyt dużo ${ }^{62}$, choć - jak wspomniano na początku - książki o sytuacji Polski w XIX wieku miały być jednym z głównych trzonów zbioru Seweryna Mielżyńskiego.

Zachowało się także kilka pojedynczych numerów czasopism z Miłosławia. Mielżyńscy czytali takie gazety jak: "Goplana. Rocznik teatralny", „Le Magasin Pittoresque”, „Le Magasin Universel”. Posiadali pojedyncze numery wydawnictw cyklicznych, takich jak: „Penelope”63, "Kalendarz Ilustrowany dla Polek"64, „Noworocznik: (kalendarz) Ilustrowany dla Polek"65.

Z wydawnictw encyklopedycznych i słownikowych z Miłosławia zachowały się jedynie dwa egzemplarze o tematyce prawniczej: Auszug aus

${ }^{59}$ La Divina Commedia di Dante Alighieri, cantica prima che contiene l'Inferno, Penig 1804.

${ }^{60}$ Ch.Th. Beauvais de Préau, Victoires, conquêtes, désastres, revers et guerres civiles des Français de 1792 à 1815, t. 5-9, 11, 13, 16, Paris 1817-1819; Ch. Sevin Quincy, Histoire militaire de regne de Louis le Gran, roy de France, t. 1-7, Paris 1726; J.H. Zopf, Grundlegung der Universalhistoire, Halle 1782; Vertot [René Aubert de], Histoire des révolutions de Suède, t. 1-2, Paris 1768; E.H.V. Noailles, Henri de Valois et la Pologne en 1572, Paris 1867; W. Hallam, Histoire constitutionelle d'Angleterre, t. 1-5, Paris 1828-1829; J.L. Motley, Histoire de Provinces-Unies des Pays-Bas, t. 1-2, Warszawa [s.a.].

${ }^{61}$ N.Th. Le Lieurre de L'Aubépin, Essai sur les manoeuvres des voltigeurs, Paris 1827; [le Roy de Bosroger], Élements de la guerre, Paris 1772; [Guibert Jacques-Antoine-Hippolyte de], Essai général de tactique, t. 2, Londres 1772; Fryderyk II Wielki, Essai sur la Grande guerre, de Main de Maitre, ou Instruction militaire de roi de Prusse, Londres 1761; K.A. Stuensee [von Karlsbach], op.cit.

${ }^{62}$ Przykładowo: J. Łukaszewski, Zabór Pruski w czasie Powstania Styczniowego 1863-64, Jassy 1870; L. Rzepecki, Katy i ofiary komuny paryskiej, Poznań 1871; A. Guttry, Pan Ludwik Mierosławski, Liège 1870; M. Chodźko, Adam Mickiewicz i Legion Polski we Włoszech, Paryż 1862; L.Z. Dębicki, Europa w chwili pogromu, Lwów 1871; M. Pietkiewicz, La Lithouanie et sa dernière insurrection, Bruxelles 1832; Polska. Dzieło poświęcone niepodległości narodu, Paryż 1836.

63 Zachowany numer: „Penelope. Taschenbuch für das Jahr 1836”, Leipzig 1835.

64 Zachowany numer: „Kalendarz Ilustrowany dla Polek na Rok...”, Warszawa 1861.

65 Zachowany numer: „Noworocznik: (kalendarz) Ilustrowany dla Polek na Rok...", Warszawa 1862. 
des Herrn Johann Georg Krünitz's ökonomisch-technologischer Encyklopädie 6 oraz Niemiecko-polski słownik wyrazów prawniczych $i$ administracyjnych ${ }^{67}$. Zapewne trafiły do Miłosławia w związku z krótkim okresem zasiadania Seweryna Mielżyńskiego w pruskiej Izbie Deputowanych (kadencja 1859-1861) $)^{68}$.

Dużą grupę tematyczną w zachowanym księgozbiorze miłosławskim stanowią książki z zakresu sztuki, architektury i fotografii, obrazujące zainteresowania artystyczne Mielżyńskiego.

\section{Księgozbiór praktyka}

Spośród zachowanych książek Seweryna Mielżyńskiego wyróżnia się zbiór tytułów związanych z działaniami, którymi właściciel Miłosławia zajmował się na poły amatorsko, na poły profesjonalnie. Należy do nich zaliczyć publikacje z zakresu inżynierii, architektury, fotografii oraz praktyczne poradniki malarstwa i rysunku dla artystów.

Zainteresowania artystyczne objawiły się u Seweryna Mielżyńskiego w czasie edukacji szkolnej. Już w okresie nauki gimnazjalnej interesował się szczególnie rysunkiem i malarstwem ${ }^{69}$. Na studiach w Genewie zajął się przede wszystkim inżynierią wojskową i konstrukcją mostów. Przez dwa lata pobierał nauki u generała Guillaume'a-Henriego Dufoura (1787-1875), wojskowego, kartografa i inżyniera, który od 1821 roku w Akademii Genewskiej prowadził kursy matematyki, geodezji, hydrauliki i geometrii ${ }^{70}$. W dowód odbycia pod jego okiem dwuletnich nauk generał wystawił Sewerynowi hrabiemu Mielżyńskiemu w 1828 roku patent $^{71}$. Pamiątką po okresie tych studiów była w bibliotece miłosławskiej książka autorstwa generała - Description du Pont suspendu en fil de fer, construit a Genève z 1824 roku (il. 13) ${ }^{72}$.

${ }^{66}$ J.G. Krünitz, Auszug aus des Herrn Johann Georg Krünitz's ökonomisch-technologischer Encyklopädie, Berlin 1805.

${ }^{67}$ Niemiecko-polski słownik wyrazów prawniczych i administracyjnych, Kraków 1862.

${ }^{68}$ L. Trzeciakowski, Postowie polscy w Berlinie 1848-1928, Warszawa 2008, s. $483-484$.

${ }^{69}$ Por. A. Wojtkowski, op.cit., s. 281-286.

${ }^{70}$ J.J. Langendorf, Dufour Guillaume-Henri, w: Dictionnaire historique de la Suisse, http://www.hls-dhs-dss.ch/textes/f/F3862.php [dostęp: 22.02.2015].

${ }^{71}$ Archiwum Państwowe w Poznaniu, Zespół Dokumenty i akta osób i rodzin, sygn. $157 / 2$.

${ }^{72}$ G.H. Dufour, Description du Pont suspendu en fil de fer, construit a Genève, Genève-Paris 1824. 


\title{
DESCRIPTION
}

\section{DU PONT SUSPENDU EN FIL DE FER,}

\author{
CONSTRUIT A GENÈVE;
}

\section{$P_{\text {AR }}$ G.-H. DUFOUR,}

Lieutenant-Colonel du Génie, Membre de la Légion d'honneur, Secrétaire de la

Société des Arts de Genève, etc., etc.

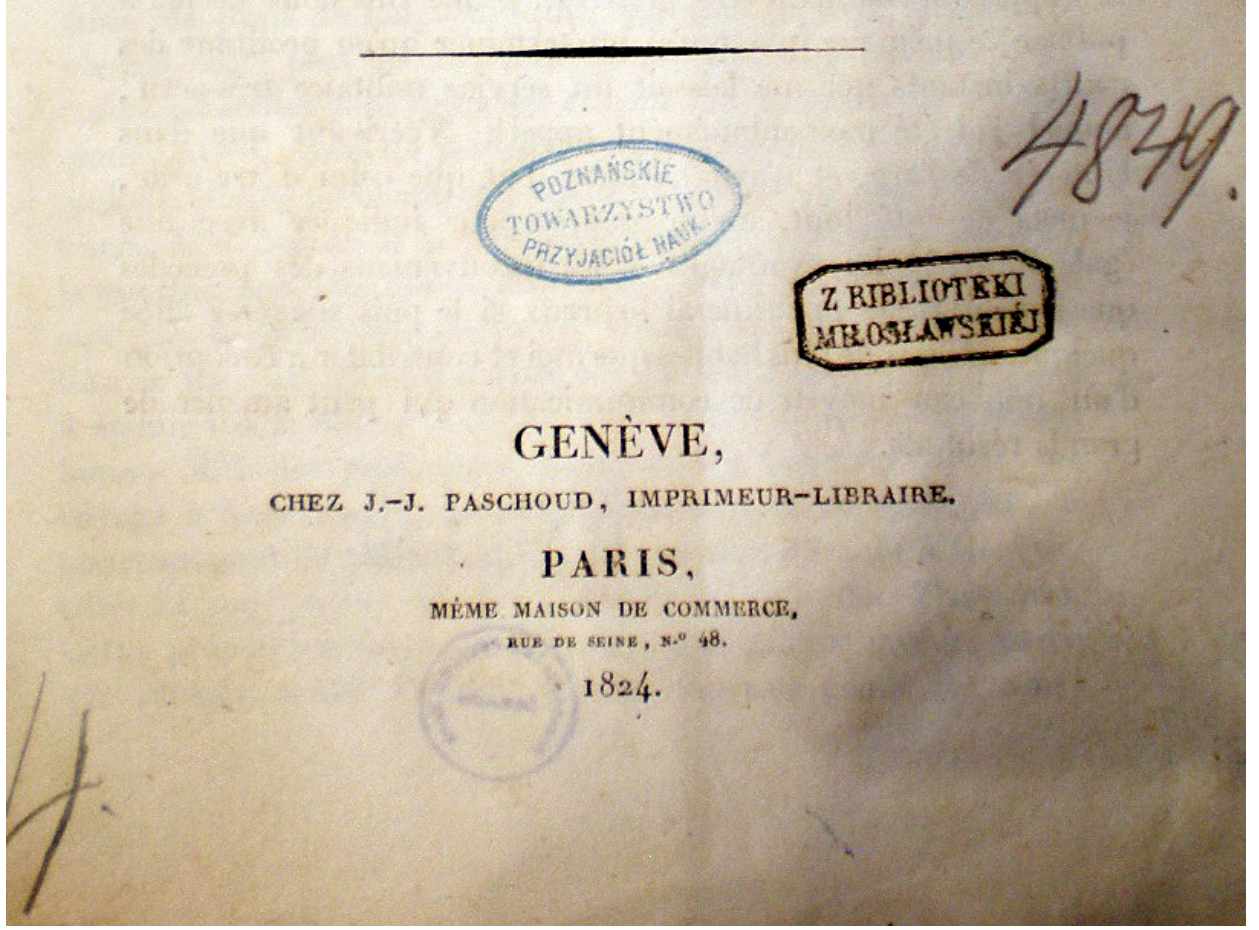

Il. 13. Strona tytułowa książki Description du Pont suspendu en fil de fer, construit a Genève Guillaume'a-Henriego Dufoura

Źródło: Biblioteka Poznańskiego Towarzystwa Przyjaciół Nauk. Fot. Kamila Kłudkiewicz. 
Z okresem studiów w zakresie inżynierii należy wiązać obecność w księgozbiorze miłosławskim również innych książek o tej tematyce: Historischer Schauplatz Carla Christiana Schramma z 1735 roku $^{73}$, Anleitung zum Brücken- und Wasserbau Johanna Christiana Kefersteina z 1791 roku $^{74}$, Géometrie descriptive Gasparda Monge z 1799 roku ${ }^{75}$ oraz dwa klasyczne dzieła z zakresu budowy fortyfikacji: Mémoire Sebastiana Vauban z $1740 \mathrm{roku}^{76}$ i Essai général de fortification Henriego Jeana de Bousmarda w wydaniu z 1797 roku $^{77}$.

Nauka inżynierii rozbudziła u Seweryna Mielżyńskiego zainteresowanie architekturą. Dała mu też praktyczne umiejętności sporządzania architektonicznych projektów. Mielżyński wykorzystał je, przebudowując kościół św. Jakuba w Miłosławiu w latach 1843-1844, a także projektując i wznosząc w 1854 roku neogotycką dzwonnicę przy tej świątyni ${ }^{78}$. Prawdopodobnie w samym Miłosławiu według projektów Seweryna Mielżyńskiego wybudowano również inne budowle ${ }^{79}$. Mielżyński projektował różne warianty przebudowy odziedziczonego pałacu w Miłosławiu, który po 1848 roku rozbudował na siedzibę rodową ${ }^{80}$.

W księgozbiorze miłosławskim oprócz podręczników (Dictionnaire général des termes d'architecture Daniela Ramée z 1868 roku ${ }^{81}$, Traité élémentaire de construction Giuseppe Borgnisa z 1823 roku $^{82}$, Manuel d'architecture Claude'a-François Toussainta z 1828 roku $^{83}$ ), praktycznych poradników

${ }^{73}$ C.Ch. Schramm, Historischer Schauplatz, in welchem die Merkwürdigsten Brücken aus allen vier Theilen der Welt, Insonderheit aber Die in den vollkommensten Stand versetzte Dreßdner Elb-Brücke, In saubern Prospecten, Münzen und andern Kupferstichen, vorgestellet und beschrieben werden: Durch brauchbare Anmerkungen und besondere Urkunden erläutert, Auch mit nöthigen Registern versehen, Leipzig 1735.

${ }^{74}$ J.Ch.F. Keferstein, Anleitung zum Brücken- und Wasserbau, Leipzig 1791.

75 G. Monge, Géometrie descriptive, Paris, An VIII [1799].

${ }^{76}$ S. Le Prestre Vauban, Mémoire pour servir d'instruction dans la conduite des siéges et dans la défense des places, Leide 1740.

77 H.J.B. de Bousmard, Essai général de fortification, et d'attaque et defense des Places, dans lequel ces deux sciences sont expliquées, t. 1-3, Berlin 1797-1799.

${ }^{78}$ Por. F. Skoraczewski, op.cit., s. 262-264.

79 Skoraczewski podaje, że były to: brama pałacowa, bożnica, tzw. Bagatela, Bażantarnia i domek ogrodnika. F. Skoraczewski, op.cit., s. 378.

${ }^{80}$ Por. A. Rogalanka, Willa Mielżyńskich w Miłosławiu, "Studia i Materiały do dziejów Wielkopolski i Pomorza" 1962, t. 7, z. 1, s. 184-222.

${ }^{81}$ D. Ramée, Dictionnaire général des termes d'architecture en français, allemand, anglais et italien, Paris 1868.

82 J.A. Borgnis, Traité élémentaire de construction appliquée a l'architecture civile, t. 1-2, Paris 1823.

${ }^{83}$ C.F. Toussaint, Manuel d'architecture ou traité de l'art de batir, t. 1-2, Paris 1828. 
z zakresu architektury (Budowanie wieyskie Piotra Świtkowskiego z 1782 roku $^{84}$ ), wzorników detali architektonicznych (Architektonische Details zum praktischen Gebrauch Ferdinanda Holza z 1844 roku $^{85}$, Die Ornamentik des Mittelalters Carla Heideloffa z 1844 roku $^{86}$ ) znajdowały się dzieła klasyczne. Mielżyński posiadał pierwsze wydanie książki jednego z głównych propagatorów architektury renesansowego mistrza Jacopa da Vignoli Cours d'architecture qui comprend les ordres de Vignole: avec des commentaires, les figures $\mathcal{E}$ descriptions de ses plus beaux batimens, $\mathcal{E}$ de ceux de Michel-Ange francuskiego architekta Augustina-Charles'a d'Avilera ${ }^{87}$. W Miłosławiu znajdowało się współczesne omówienie klasycznych założeń Vignoli i d'Avilera, czyli Le Vignole des Architectes Charles'a Normanda z 1827 roku $^{88}$.

Mielżyński posiadał również zbiór dzieł poświęconych historii architektury: An History of the Origin and establishment of gothic architecture Johna Sidneya Hawkinsa z 1813 roku $^{89}$, Geschichte der Architektur Wilhelma Lübkego z 1865 roku $^{90}$, Beiträge zur Geschichte der Ausbildung der Baukunst Christiana Ludwiga Stieglitza z 1834 roku $^{91}$.

Wśród książek z księgozbioru miłosławskiego wyróżnia się niewielki, ale znakomity zbiór dzieł poświęconych fotografii. Seweryn Mielżyński był jednym z pierwszych Polaków zainteresowanych możliwościami, które daje nowy wynalazek. Świadczy o tym fakt, że kilka miesięcy po oficjalnym zatwierdzeniu przez Francuską Akademię Nauk w sierpniu 1839 roku nowej formy utrwalania obrazu - dagerotypii Seweryn Mielżyński przetłumaczył z języka francuskiego na polski opis zasad działania wynalazku Louisa Jacques'a Daguerréa. Najprawdopodobniej Mielżyński

${ }^{84}$ P. Świtkowski, Budowanie wieyskie dziedzicom dobr y possessorom toż wszystkim iakażkolwiek zwierzchność po wsiach i miasteczkach maiących do uwagi y praktyki dane, Warszawa-Lwów 1782.

${ }^{85}$ F.W. Holz, Architektonische Details zum praktischen Gebrauch, z. 1-10, Berlin 1844.

${ }^{86}$ C. Heideloff, Die Ornamentik des Mittelalters. Eine Sammlung auserwählter Verzierungen und Profile byzantinischer und deutscher Architektur, Nürnberg-Berlin 1844.

87 A.Ch. d'Aviler, Cours d'architecture qui comprend les ordres de Vignole: avec des commentaires, les figures $\mathcal{E}$ descriptions de ses plus beaux batimens, $\mathcal{E}$ de ceux de MichelAnge, Paris 1691.

${ }^{88}$ C. Normand, Le Vignole des Architectes et des élèves en Architecture, ou nouvelle traduction des règles des cing ordres d'architecture de Jacques Barrozzio de Vignole, Paris 1827.

${ }^{89}$ J. Sidney Hawkins, An History of the Origin and establishment of gothic architecture, comprehending also an account, London 1813.

${ }^{90}$ W. Lübke, Geschichte der Architektur von den ältesten Zeiten bis auf die Gegenwart, Leipzig 1865.

${ }^{91}$ Ch.L. Stieglitz, Beiträge zur Geschichte der Ausbildung der Baukunst, Leipzig 1834. 
osobiście obserwował pokazy urządzane przez Daguerre'a w 1839 roku w Paryżu. Tam też zaraz po ukazaniu się drukiem pierwszej broszury wynalazcy przetłumaczył jej treść i przesłał ją Wiktorowi Kurnatowskiemu do Poznania ${ }^{92}$. W grudniu 1839 roku nakładem braci Scherków ukazała się w Poznaniu przetłumaczona przez Mielżyńskiego broszura Daguerreotyp $i$ Dijorama, czyli dokładny $i$ autentyczny opis postępowania $i$ aparatu mojego, do utrwalania obrazów ciemnicy optycznej (camera obscura), przytem o rodzaju i sposobie malowania i oświetlenia w Dijoramie.

Mielżyński zafascynował się fotografią. Z przekazów źródłowych wiadomo, że sam wykonywał zdjęcia ${ }^{93}$, niestety żadna $\mathrm{z}$ jego fotografii nie zachowała się do naszych czasów. Natomiast na półkach biblioteki w Miłosławiu znajdował się zbiór książek dokumentujących rozwój tej nowej dziedziny w XIX wieku. Mielżyński posiadał podręcznik francuskiego malarza i chemika Charles'a Guillaume'a Alexandre'a Bourgeois, w którym autor objaśniał artystom, jak posługiwać się znaną od starożytności camerą obscurą ${ }^{94}$, prostym urządzeniem optycznym poprzedzającym aparat fotograficzny.

W zbiorach Mielżyńskiego znajdował się zestaw poradników dla dagerotypistów $\mathrm{w}$ różnych językach (Traité général de photographie Désiré van Monckhovena $\mathrm{z} 1856$ roku $^{95}$ i tegoż Procédé nouveau de photographie sur plaques de fer z 1858 roku' ${ }^{96}$, Handbuch der practischen Photographie Ludwiga Gustava Kleffela z 1860 roku $^{97}$, anonimowy Guide de photographie z 1854 roku $^{98}$, Les quatre branches de la photographie Auguste'a Belloca z 1855 roku $\left.^{99}\right)$. Mielżyński miał $\mathrm{w}$ swych zbiorach opracowanie ojca polskiej fotografii - Maksymiliana Strasza zatytułowane Fotografia czyli zbiór środków używanych do zdejmowania obrazów za pomoca światła, na papierze lub na szkle z 1857 roku $^{100}$. Właściciel Miłosławia śledził też pojawienie się nowych tech-

\footnotetext{
92 I. Płażewski, Dzieje polskiej fotografii 1839-1939, Warszawa 2003, s. 50.

93 F. Skoraczewski, op.cit., s. 389.

${ }^{9}$ Ch.G.A. Bourgeois, Manuel d'optique expérimentale à l'usage des artistes et des physiciens, Paris 1821.

95 D. van Manckhoven, Traité général de photographie... suivi des applications, Paris 1856.

96 D. van Manckhoven, Procédé nouveau de photographie sur plaques de fer, Paris 1858 lin 1860 .

97 L.G. Kleffel, Handbuch der practischen Photographie, Vollständiges Lehrbuch, Ber-

98 Guide de photographie, Paris 1854.

99 A. Belloc, Les quatre branches de la photographie, Paris 1855.

100 M. Strasz, Fotografia czyli zbiór środków używanych do zdejmowania obrazów za pomoca światła, na papierze lub na szkle, Warszawa 1857.
} 
nik fotograficznych. Posiadał opracowania o technice kolodionowej, która od lat 50. XIX wieku wypierała dagerotypię - Handbuch der Photographie auf Collodion Johanna Paula Eduarda Lieseganga z 1861 roku ${ }^{101}$, Traité complet de photographie sur collodion Alphonse'a de Brébissona z 1855 roku ${ }^{102}$.

Mielżyński miał wykorzystywać fotografię, jak wielu artystów w XIX wieku, do pracy malarskiej ${ }^{103}$. Jego aktywność na polu artystycznym, choć przybierała głównie formy amatorskiej pasji, której poświęcał się w zaciszu domowym, kilkukrotnie wyszła poza ramy nieprofesjonalnego zajęcia.

Przede wszystkim właściciel Miłosławia miał wykształcenie w dziedzinie artystycznej. Przynajmniej przez kilka lat pobierał nauki u genewskiego malarza, głównego reprezentanta akademizmu w tym mieście, znanego również z wystaw paryskich - Jeana Leonarda Lugardona (1801-1884). Mielżyński prawdopodobnie zaczął pobierać lekcje malarstwa w atelier popularnego w Genewie malarza około 1836 roku, kiedy po raz drugi odwiedził Szwajcarię, tym razem z powodu przymusowej popowstaniowej emigracji. Wielce prawdopodobne jest, że w tym samym czasie odwiedzał w Genewie atelier malarza irlandzkiego pochodzenia, mieszkającego w latach 30. XIX wieku w tym mieście - Francisa Danby'ego $(1793-1861)^{104}$.

Po powrocie z emigracji do Miłosławia Mielżyński do końca życia zajmował się malarstwem. W pałacu miłosławskim posiadał własne atelier, w którym malował, a także konserwował stare obrazy ${ }^{105}$. W doskonaleniu umiejętności restaurowania starych dzieł niewątpliwie przydatny był traktat malarza i chemika Léonora Mériméego, opisujący różne techniki malarskie stosowane od czasów nowożytnych - Le traité de la peinture à l'huile ou des proces matériels employés dans ce genre de peinture depuis $\mathrm{Hu}$ bert et Jean Van-Eyck jusqu'à nos jours z 1830 roku.

101 J.P.E. Liesegang, Handbuch der Photographie auf Collodion. Positive und Negative auf Glas, Berlin 1861.

102 A. de Brébisson, Traité complet de photographie sur collodion, répertoire de la plupart des procédés connus, Paris 1855.

103 F. Skoraczewski, op.cit., s. 389.

104 Por. K. Kłudkiewicz, Wybór i konieczność..., s. 84-85.

105 Po zakupie kolekcji obrazów barona Rastawieckiego część płócien Mielżyński samodzielnie restaurował w Miłosławiu, o czym wspomina w liście do Józefa Ignacego Kraszewskiego Franciszka Mielżyńska (list z dnia 2 października 1870 roku. Waber via Bromberg Calm, BJ, sygn. 6521 IV, k. 174-175). O tym zajęciu Mielżyńskiego wspominał również Leon Kapliński w liście do Jana Działyńskiego (por. List Leona Kaplińskiego do Jana Działyńskiego, z Miłosławia, lipiec 1871 r. (?), BK 7472, k. 140). 
Seweryn Mielżyński namalował obrazy do kościoła w Miłosławiu ${ }^{106}$, wystawiał swoje płótna na wystawach w Poznaniu ${ }^{107} \mathrm{i}$ być może w Monachium $^{108}$. Zachowany dorobek malarski właściciela Miłosławia można było obejrzeć na wystawie w poznańskim Muzeum Wielkopolskim dopiero w 1934 roku $^{109}$. Pokazano wówczas publiczności 80 obrazów Seweryna Mielżyńskiego.

W swojej bibliotece Mielżyński posiadał zbiór poradników malowania, rysowania i wykreślania perspektywy malarskiej dla amatorów i artystów. Należy do nich zaliczyć: Art de peindre à l'aquarelle, enseigné en vingt-huit leçons Thomasa Smitha z 1828 roku $^{110}$, Traité de perspective linéaire Louisa Nicolasa Lespinasse'a z 1823 roku $^{111}$, Lectures on the principles and practice of perspective Johna George'a Wooda z 1809 roku ${ }^{112}$, Manuel de perspective, du dessinateur et du peintre Armanda Denisa Vergnauda z 1826 roku ${ }^{113}$.

Zastanawia obecność w bibliotece miłosławskiej dość sporego zbioru poradników poświęconych malarstwu na szkle i emalierstwu. Były to XVIII- i XIX-wieczne książki z praktycznymi wskazówkami dotyczącymi wyrobu porcelany, szkła i ich dekorowania ${ }^{114}$. W zachowanych źródłach

106 F. Skoraczewski, op.cit., s. 265-266.

107 Przykładowo na wystawie zorganizowanej przez Towarzystwo Przyjaciół Sztuk Pięknych Wielkiego Księstwa Poznańskiego wystawił w 1857 roku trzy swoje krajobrazy. Por. Wystawy Towarzystwa Sztuk Pięknych w Poznaniu (1837-1857). Materiały źródłowe, oprac. M. Warkoczewska, Warszawa-Poznań 1991, s. 69.

108 Mielżyński przyjaźnił się z kolonią polskich artystów w Monachium, odwiedzał wystawy w tym mieście. Pozwolił również młodemu artyście Henrykowi Redlichowi wystawić na I Międzynarodowej Wystawie Sztuki w 1869 roku w tym mieście rysunek na podstawie jednego ze swoich obrazów (według Mottego była to litografia obrazu Kazanie Chrystusa w łodzi Mielżyńskiego). Por. M. Motty, op.cit., s. 123.

109 Por. J. Orańska, Seweryn Mielżyński jako artysta malarz (1804-1872) z okazji wystawy jego prac w galerji im. Mielżyńskich, "Dziennik Poznański”, nr 16, 20.01.1934, s. 2.

110 Art de peindre a l'aquarelle, enseigné en vingt-huit leçons, przeł. Th. Smith, Paris 1828 .

111 L.N. Lespinasse, Traité de perspective linéaire à l'usage des artistes, Paris 1823.

112 J.G. Wood, Lectures on the principles and practice of perspective, London 1809.

113 A.D. Vergnaud, Manuel de perspective, du dessinateur et du peintre, Paris 1826.

114 D. d'Arclais de Montamy, Traité des couleurs pour la peinture en émail et sur la porcelaine, Paris 1765; A. Neri, Ch. Merret, J. Kunckel, Art de la verrerie, Paris 1752; J. Haudicquer de Blancourt, L'art de la verrerie, Paris 1718; The Cainet Cyclopaedia. Conducted by the Rev. Dionysius Lardner, LL. D., FRS, assisted by Eminent Literary and Scientific Men. A Treatise on the progressive improvement and present state of the manufacture of Porcelain and Glass, London 1832; W. Cooper, The crown glass cutter and glacier's manuel, Edinbourgh 1835; M.E.F. Reboulleau, Nouveau manuel complet de la peinture sur verre, sur porcelaine et sur émail, Paris 1843. 
nie ma jednak wzmianki o tym, że oprócz licznych działań artystycznych ${ }^{115}$ Seweryn Mielżyński tworzył też bądź dekorował szkło.

\section{Księgozbiór kolekcjonera sztuki}

Kolejny, liczny, zawierający dziś około 40 tytułów, zbiór książek z biblioteki miłosławskiej wiązał się z kolekcjonerską pasją Seweryna Mielżyńskiego i jego długoletnimi staraniami o stworzenie kolekcji europejskiego malarstwa dawnego, która - udostępniana w Miłosławiu - wypełniłaby brak muzeum sztuki w Wielkopolsce ${ }^{116}$.

Z powodu braku źródeł początki kolekcjonerstwa Seweryna Mielżyńskiego są trudne do zrekonstruowania. Prawdopodobnie na początku, oprócz wspomnianego już zbioru minerałów, Mielżyński zbierał grafikę. Pierwsze informacje o kolekcji dzieł sztuki znajdującej się w Miłosławiu pochodzą z 1844 roku i dotyczą rycin ${ }^{117}$.

Niewiele wiadomo o tym zbiorze. Mielżyński miał w Miłosławiu kilka ważnych książek z zakresu grafiki, swoistych podręczników dla znawców i zbieraczy. Dzieła te zawierały wykazy oznaczeń, monogramów, inicjałów, jakimi rytownicy posługiwali się od stuleci. W swoim księgozbiorze Mielżyński posiadał Anzeige und Auslegung der Monogramatum Johanna Friedricha Christa z 1747 roku ${ }^{118}$, Notices sur les graveurs Jeana-Pierre'a Baverela i François Malpe'a z 1807-1808 roku ${ }^{119}$, Monogrammenlexicon für den Handgebrauch Johanna Conrada Stellwaga z 1830 roku $^{120}$, A Treatise on Wood Engraving Johna Jacksona z 1839 roku $^{121}$.

115 Oprócz projektów architektonicznych, malarstwa i fotografii Mielżyński miał wykonywać również projekty mebli. Por. informacje o neogotyckim fotelu z herbem Nowina zachowanym dziś w zbiorach Muzeum Narodowego w Poznaniu: Ars una species mille. 150 dzieł na 150-lecie Muzeum Narodowego w Poznaniu ze zbiorów Poznańskiego Towarzystwa Przyjaciót Nauk, red. D. Suchocka, Poznań 2007, s. 254.

116 Szczegółowo: K. Kłudkiewicz, Wybór i konieczność..., s. 80-104.

117 Por. tekst podpisany inicjałami W.M., O wystawie obrazów w Poznaniu, „Przyjaciel Ludu”, nr 45, 10.05.1845, s. 357: „Miłosław hr. Mielżyńskiego, ma nader bogaty zbiór rycin, a zapewne i piękne obrazy".

118 J.F. Christ, Anzeige und Auslegung der Monogramatum, Leipzig 1747.

119 J.P. Baverel, F. Malpe, Notices sur les graveurs qui nous ont laissé des estampes marquées de monogrammes, chiffres, rébus, lettres initiales, avec une description de leurs plus beaux ouvrages, Besançon 1807-1808. 1830

120 J.C. Stellwag, Monogrammenlexicon für den Handgebrauch, Frankfurt am Main

${ }^{121}$ J. Jackson, A Treatise on Wood Engraving, historical and practical. With upwards of three hundred illustrations, engraved on wood, London 1839. 
Wiadomo, że najważniejszym dziełem $\mathrm{z}$ historii grafiki, opracowaniem wręcz podstawowym dla XIX-wiecznych kolekcjonerów, czyli Le Peintre-graveur Adama von Bartscha ${ }^{122}$, Mielżyński zainteresował się bardzo późno. Dopiero w 1870 roku Franciszka Mielżyńska pisała do Józefa Ignacego Kraszewskiego, który wielokrotnie pomagał właścicielowi Miłosławia w zakupach książek i dzieł sztuki w Dreźnie:

Pisząc ostatni list, zapomniałam polecenia Seweryna, żeby prosić Pana gdybyś napotkał u jakiegoś antykwariusza dzieło, które sobie taniej nabyć życzył, a które w handlu jest rzadkie i drogie, żebyś był łaskaw nabyć go dla niego. Tytuł jest: Bartsch le peintre gravure ${ }^{123}$.

Ta informacja może sugerować, że około 1870 roku, a więc w czasie, kiedy ukończył budynek galerii miłosławskiej dla pomieszczenia swojej kolekcji malarstwa, Mielżyński zamierzał uporządkować zbiór rycin. Przy takim zajęciu korzystanie z dzieła Bartscha było wręcz niezbędne. Nie wiadomo jednak, czy dzieło Le peintre-graveur trafiło do biblioteki miłosławskiej. Mielżyński na pewno posiadał inne opracowanie wiedeńskiego znawcy grafiki katalog dzieł graficznych holenderskiego pejzażysty Antona Waterloo ${ }^{124}$.

Niewątpliwie największym osiągnięciem Mielżyńskiego jako kolekcjonera były zbiory obrazów. Powstawały one sukcesywnie w ciągu prawdopodobnie kilkudziesięciu lat, zaś zwieńczeniem długoletniej pasji było przeniesienie płócien do budynku przypałacowej galerii w 1870 roku. Kolekcja liczyła wówczas 194 obrazy mistrzów włoskich, hiszpańskich, francuskich, flamandzkich i holenderskich, niemieckich, angielskich i polskich.

Dla kolekcjonera poszukującego dzieł na rynku sztuki, kupującego i porównującego obrazy danego mistrza niezbędne jest zwiedzanie kolekcji publicznych i prywatnych, podziwianie oryginałów, a także oglądanie ich graficznych kopii. Do tego wszystkiego służył w Miłosławiu zbiór katalogów europejskich muzeów, prywatnych kolekcji, wystaw czy aukcji zbiorów. Mielżyński posiadał katalogi zbiorów Luwru ${ }^{125}$, paryskiej

122 [Johann] Adam [Bernhard] von Bartsch (1757-1821) opublikował w latach 1803-1821 w 21 tomach katalog sztychów starych mistrzów. Le Peintre-graveur obejmował flamandzkich, holenderskich, niemieckich i włoskich artystów grafików od XV do XVII wieku.

${ }^{123}$ List Franciszki Mielżyńskiej do Józefa Ignacego Kraszewskiego z dnia 30 kwietnia 1870 r. (dopisek z dnia 4 maja) z Miłosławia, Biblioteka Jagiellońska, sygn. 6521 IV, k. 158.

124 A. von Bartsch, Anton Waterlo's Kupferstiche, Wien 1795.

125 F. Villot, Notice des tableaux exposés dans les galeries du Musée Impérial du Louvre, t. 1-3, Paris 1865-1866. 
Biblioteki Królewskiej ${ }^{126}$, muzeów w Berlinie ${ }^{127}$, Wiedniu ${ }^{128}$, Hamburgu ${ }^{129}$, Neapolu ${ }^{130}$, prywatnych kolekcji Atanazego Raczyńskiego w Berlinie ${ }^{131}$, księcia Wilhelma Fryderyka z dynastii Orańskiej w Brukseli ${ }^{132}$, galerii elektorów saskich w Dreźnie ${ }^{133}$ oraz katalogi dwóch poznańskich wystaw obrazów z $1860^{134}$ i 1866 roku $^{135}$.

W orientacji na rynku dzieł sztuki miały pomagać kolekcjonerowi publikacje przeznaczone dla koneserów malarstwa, pozwalające odróżniać dzieło mistrza od prac jego warsztatu czy kopii, takie jak Guide théorique Théodore'a Lejeune'a z lat 1864-1865 ${ }^{136}$.

Najistotniejszym zespołem publikacji w Miłosławiu był zbiór dzieł z historiografii i historii sztuki. Mielżyński miał w swojej kolekcji książki nowożytnych badaczy sztuki: wydanie Ikonologii Cesare Ripy z 1618 roku ${ }^{137}$ oraz co najmniej dwa przykłady popularnych w XVII i XVIII wieku żywotów malarzy: Le vite de' pittori, scultori et architetti moderni Giovanniego Belloriego z 1672 roku $^{138}$ i Abrégé de la vie des peintres Johanna Augusta Lehningera z 1781 roku $^{139}$.

${ }^{126}$ J. Duchesne, Notice des estampes exposées a la Bibliotheque Royale, Paris 1837.

127 F. Kugler, Beschreibung der in der Königl. Kunstkammer zu Berlin vorhandenen Kunst-Sammlung, Berlin 1838.

128 A. Krafft, L'école moderne de la Galerie de Tableaux Imériale et Royale, Vienne 1857.

129 Verzeichniss der Bilder der öffentlichen städtischen Gemälde-Gallerie in Hamburg, Hamburg 1850.

${ }^{130}$ Raccolta de piu belli ed interessanti Dipinti, Musaici ed altri monumenti rinvenuti negli Scavi, di Ercolando di Pompei di Stabia che ammiransi nel Museo Nazionale, Napoli 1871.

131 A. Raczyński, Katalog der Raczyńskischen-Bilder-Sammlung Verfasst von..., Berlin 1856.

132 C.J. Nieuwenhuys, Description de la collection des tableaux qui ornent le palais de S. A. R. Mgr le prince d'Orange à Bruxelles, Bruxelles 1837.

133 [J.A. Lehninger], Abrégé de la vie des peintres dont les tableaux composent la galerie electorale de Dresde. Avec le détail de tous les tableaux de cette collection $\mathcal{E}$ des eclaircissemens historiques sur les chef-d'oeuvres de la peinture, Dresde 1782.

${ }^{134}$ Verzeichniss der Oelgemaelde des verstorbenen Domprobst und General-Vikar Kiliński und des Gutsbesitzers Rejewski in Posen, Posen 1860.

135 Spis drugiej wystawy obrazów w pałacu Działyńskich na korzyść ubogich miejscowych w Poznaniu, Poznań 1866.

136 Th. Lejeune, Guide théorique et pratique de l'Amateur de Tableaux études sur les imitateurs et les copistes des maitres de toutes les écoles dont les oeuvres forment la base ordinaire des Galleries, t. 1-3, Paris 1864-1865.

137 C. Ripa, Nova iconologia, Padova 1618.

138 G.P. Bellori, Le vite de' pittori, scultori et architetti moderni, Roma 1672.

139 [J.A. Lehninger], op.cit. 
Kolekcjoner z Miłosławia posiadał również bardzo popularne w XVIII wieku słowniki nowożytnych malarzy europejskich $\mathrm{w}$ wydaniach $\mathrm{z}$ lat 40. XIX wieku. Były to: A General Dictionary of Painters Matthew Pilkingtona ${ }^{140}$, Abregé de la vie des plus fameux peintres Antoine'a Josepha Dezalliera d'Argenville'a i La Vie des peintres flamands, allemands et hollandais Jeana-Baptiste'a Descampsa ${ }^{141}$. Były to książki znaczące dla kształtowania się XVIII-wiecznego koneserstwa, kolekcjonerstwa oraz ustalenia swoistego kanonu najpopularniejszych nowożytnych artystów ${ }^{142}$. Pod względem pisarstwa o sztuce nie wychodziły jednak poza ukształtowany przez Giorgia Vasariego w jego Le vite de'più eccelenti architetti, pittori, et scultori italiani z 1550 roku schemat zestawiania kilkunastu biografii artystów ${ }^{143}$.

Oprócz opracowań biograficznych Mielżyński posiadał też dzieła przełomowe dla narodzin historii sztuki jako dyscypliny naukowej. W jego bibliotece znajdowało się francuskie tłumaczenie Dziejów sztuki starożytnej Johanna Winckelmanna ${ }^{144}$, pracy wyznaczającej narodziny nowoczesnej, naukowej historii sztuki ${ }^{145}$.

Właściciel Miłosławia orientował się w najważniejszych i bieżących publikacjach z połowy XIX wieku. Posiadał książki niemieckich historyków

${ }^{140}$ Matthew Pilkington (1701-1774) opublikował The Gentleman's and Connoisseurs's Dictionary of Painters w 1770 roku. Książka była wznawiana wielokrotnie. Mielżyński posiadał wydanie: M. Pilkington, A General Dictionary of Painters; containing Memoirs of the lives and Works of the most emitent Professors of the Art of Painting, from this revival by Cimabue, in the year 1250, to the present time, London 1840.

141 Antoine-Joseph Dezallier d'Argenville (1680-1765) wydał Abregé de la vie des plus fameux peintres $\mathrm{w}$ trzech tomach w latach 1745-1752. Jean-Baptiste Descamps (1706-1791) w 1763 roku opublikował La Vie des peintres flamands, allemands et hollandais. Mielżyński posiadał pięciotomowe wydawnictwo zawierające dzieła obydwu autorów: J.B. Descamps, A.J. Dezallier d'Argenville, Vie des Peintres flamands et hollandais, réunie a celle des peintres italiens et français, t. 1-5, Marseille 1842-1843.

142 Por. G. Maës, Dutch art collections and connoisseurship in the eighteenth century: the contributions of Dezallier d'Argenville and Descamps, "Similous: Netherlands Quarterly for the History of Art" 2009/2010, t. 34, nr 3/4, s. 226-238; P. Michel, Dezallier d'Argenville's "Abrégé de la vie des plus fameux peintres": a guide for contemporary collectors or a survey of the taste for paintings of the northern schools?, "Simiolus: Netherlands Quarterly for the History of Art" 2009/2010, t. 34, nr 3/4, s. 212-225.

143 Por. również zmiany, jakie zachodziły w konstruowaniu biografii artystów na przełomie XVIII i XIX wieku, szczegółowo: K. Hellwig, Von der Vita zur Künstlerbiographie, Oldenbourg 2005.

${ }^{144}$ J.J. Winckelmann, Histoire de l'art de l'antiquité, t. 3, Leipzig 1781.

145 Por. W. Bałus, Nowy system wiedzy, w: J.J. Winckelmann, Dzieje sztuki starożytnej, przeł. T. Zatorski, oprac. W. Bałus, Kraków 2012, s. XIII-XXVII. 
sztuki: Johanna Davida Passavanta ${ }^{146}$, Johanna Friedricha Overbacka ${ }^{147}$, Franza Kuglera ${ }^{148}$, Jeana-Baptiste'a-Louisa-George'a Seroux d'Agincourta ${ }^{149}$, a także jedne z pierwszych polskich opracowań na temat sztuki, utrzymane jeszcze bardziej w duchu historiografii (aniżeli historii sztuki) ${ }^{150}$, a nawet o charakterze przewodnikowym ${ }^{151}$. Posiadał niemal komplet prac francuskiego historyka sztuki Pierre'a-Marie Gault de Saint-Germaina ${ }^{152}$ oraz przynajmniej jeden z tomów dziesięciotomowego dzieła Alfreda Michielsa ${ }^{153}$.

Ta zachowana do dziś w niewielkim stopniu biblioteczka dzieł z historii sztuki miała dla Seweryna Mielżyńskiego duże znaczenie. Zamysłem kolekcjonera było bowiem ukazanie w miłosławskiej galerii historii europejskiego malarstwa od XV do XVIII wieku. W tym celu rozwijał przez całe życie wiedzę z zakresu historii sztuki, pogłębiał informacje o artystach i obrazach, kupował najnowsze wydania dzieł traktujących o historii malarstwa.

Kolekcjoner nie tylko zebrał i uszeregował chronologicznie kilkadziesiąt nowożytnych obrazów europejskich, ale również opisał swój zbiór. W 1870 roku Seweryn Mielżyński sporządził własnoręcznie Spis obrazów zbioru miłosławskiego ${ }^{154}$. W 1871 roku napisał wersję w języku francuskim ${ }^{155}$, której treść wiernie odpowiada pierwszemu, polskiemu spisowi.

146 J.D. Passavant, Kunstreise durch England und Belgien..., Frankfurt am Main 1833; idem, Die christliche Kunst in Spanien, Leipzig 1853.

147 J.F. Overback, Triumph der Religion in der Kunst, Frankfurt/M [s.a.].

148 F. Kugler, op.cit.

149 J.B.L.G. Seroux d'Agincourt, Sammlung von Denkmälern der Architectur, Sculptur und Malerei von IV bis zum XVI Jahrhundert, Frankfurt am Main 1840.

150 F.M. Sobieszczański, Wiadomości historyczne o sztukach pięknych w dawnej Polsce, t. 1-2, Warszawa 1847-1849. Por. J. Polanowska, Historiografia sztuki polskiej w latach 1832-1863, Warszawa 1995.

151 J.A. Łepkowski, Sztuka. Zarys jej dziejów, zarazem podręcznik dla uczacych się i podróżujacych, Kraków 1872.

152 P.M. Gault de Saint-Germain, Vie de Nicolas Poussin, considéré comme chef de l'école françoise, Paris 1806; idem, Ecole italienne. Guide des amateurs de peinture ou histoire et procés-verbaux des auteurs, des collections géné et particulières, des magasins et des ventes, Paris 1835; idem, Guide des amateurs de tableaux pour les écoles allemande..., t. 1-2, Paris 1841; Leonardo da Vinci, Traité de la peinture. Precédé de la vie de l'auteur et du catalogue de ses ouvrages avec des notes et observations par P[ierre] Marie Gault de Saint Germain, Paris 1803.

153 A. Michiels, Histoire de la Peinture Flamande, depuis ses débuts jusqu'en 1864, t. 6, Paris 1868.

154 S. Mielżyński, Spis obrazów zbioru miłosławskiego, 1870, rękopis, Archiwum Muzeum Narodowego w Poznaniu, sygn. 1414/49.

155 S. Mielżyński, Catalogue des Tableaux de la Collection de Miłosław, 1871, rękopis, Archiwum Muzeum Narodowego w Poznaniu, sygn. 1414/50. 
Mielżyński uporządkował obrazy na podstawie ich przynależności do szkół narodowych. Kolejno są to: szkoła włoska (podzielona na rzymska, bolońską wenecka, neapolitańską lombardzką), hiszpańska, francuska, połączone flamandzka i holenderska, niemiecka, angielska i polska. Pod względem liczby dzieł wyróżniają się zdecydowanie prace ze szkoły włoskiej (63 obrazy) i szkoły niderlandzkiej (62 obrazy). W obrębie każdej ze szkół Mielżyński opisał dzieła poszczególnych artystów, poprzedzając je krótkim biogramem każdego twórcy.

Pod względem metody opisu katalog autorstwa Mielżyńskiego łączy dwa funkcjonujące dotychczas w piśmiennictwie na temat sztuki spojrzenia na historię malarstwa - wspominany już model biograficzny oraz podział na szkoły narodowe ${ }^{156}$. Ponadto w konstrukcji katalogu i opisach obrazów można odnaleźć inspiracje współczesnymi poglądami estetycznymi, w tym zwłaszcza teoriami serdecznego przyjaciela Seweryna Mielżyńskiego - ucznia Georga Friedricha Hegla, wielkopolskiego filozofa Karola Libelta (1807-1875) ${ }^{157}$.

Poza tym w tekście katalogu Mielżyńskiego znajdziemy wiele bezpośrednich nawiązań do opracowań, które posiadał w swojej bibliotece.

Przede wszystkim forma spisu zbioru miłosławskiego przypomina popularne, wydawane od XVIII wieku katalogi kolekcji prywatnych i muzealnych. Miały one charakter przewodników, zawierały podstawowe, krótkie informacje dla zwiedzających - o dziełach i ich autorach. Konstrukcja spisu Mielżyńskiego jest taka jak w tego typu wydawnictwach: najpierw podaje on imię i nazwisko malarza, następnie jego krótki biogram, dalej tytuł dzieła z kolekcji, jego krótki opis i wymiary. W bibliotece Mielżyńskiego ten typ opisu zbiorów pojawił się na przykład w katalogu kolekcji elektorów saskich w Dreźnie z 1782 roku ${ }^{158}$.

W niektórych sformułowaniach Mielżyńskiego pobrzmiewa echo słów francuskiego autora Pierre'a-Marie Gault de Saint-Germaina (1752$1842)^{159}$. Ten badacz w swoich opracowaniach wypromował XVII-wiecznego francuskiego malarza działającego w Italii Nicolasa Poussina na ojca i głównego mistrza szkoły francuskiej ${ }^{160}$. U Mielżyńskiego opis obrazów

156 Zob. K. Kłudkiewicz, Wybór i konieczność..., s. 95-97.

157 Szczegółowo analizuję kolekcję obrazów Seweryna Mielżyńskiego i katalog tego zbioru jego autorstwa w: ibidem, s. 92-95.

158 [J.A. Lehninger], op.cit.

159 Por. C. Murgia, Gault de Saint-Germian, Pierre-Marie (1752-1842), w: Dictionnaire critique des historiens de l'art actifs en France de la Révolution à la Première Guerre mondiale, red. P. Sénéchal, C. Barbillon, Paris site web de l'Institut National d'Histoire de l'Art, 2009, http://www.inha.fr/spip.php?article2331 [dostęp: 26.05.2015].

${ }^{160}$ Gault de Saint-Germain poświęcił Nicolasowi Poussinowi swoją książkę: Vie de Nicolas Poussin... 
ze szkoły francuskiej znajdujących się w jego kolekcji koncentruje się wokół tego „najpierwszego mistrza francuskiego”161, a twórczość innych Francuzów opisywana jest przez stosunki z Poussinem ${ }^{162}$. Z francuskim autorem łączy ponadto Mielżyńskiego twórczość artystyczna. Obydwaj byli malarzami i podobnie jak Gault de Saint-Germain Mielżyński, opisując obrazy ze swojej kolekcji, często komentuje ich wykonanie, poprawność rysunku ${ }^{163}$ czy kolorystykę ${ }^{164}$.

Natomiast w opisie obrazów szkoły flamandzkiej w Miłosławiu Mielżyński akcentuje kluczowe miejsce Jana van Eycka dla powstania i rozwoju malarstwa flamandzkiego i opiera się na założeniach Alfreda Michielsa (1819-1892), poszukującego w latach 40. XIX wieku źródeł „narodowej sztuki flamandzkiej i holenderskiej”"165 w twórczości braci van Eycków.

\section{Podsumowanie}

Zachowany dziś w formie szczątkowej księgozbiór z Miłosławia mimo niewielkiej objętości ukazuje zainteresowania Seweryna Mielżyńskiego. W Miłosławiu, podobnie jak w innych polskich bibliotekach ziemiańskich i arystokratycznych ${ }^{166}$, dużo miejsca zajmowała beletrystyka polska i zachodnia. Na półkach miłosławskiej biblioteki stały również książki o tematyce historycznej, dotyczące wojskowości i aktualnej sytuacji politycznej w Europie i na ziemiach polskich. Mieszkańcy pałacu czytali też czasopisma. Można zakładać, że korzystali z wydawnictw encyklopedycznych i słowników językowych.

Duży zespół książek pozwala zrekonstruować teoretyczny warsztat Mielżyńskiego-architekta, Mielżyńskiego-fotografa, Mielżyńskiego-mala-

161 S. Mielżyński, Spis obrazów..., k. 52.

162 Gaspard Dughet jest przede wszystkim szwagrem Nicolasa Poussina, François Millet malował „w duchu Poussina”, Jacques Stella „zupełnie się poddał radom Poussina”, dzieła Eustache’a Le Sueura „ustaliły zbawienny wpływ Poussina”. Por. ibidem, k. 57-59.

163 Por. ibidem, k. 60 (biogram Sebastiana Bourdona).

164 Por. ibidem, k. 85 (biogram Rubensa).

165 Por. F.R. Martin, Michiels Alfred (1813-1892), w: Dictionnaire critique des historiens de l'art actifs en France de la Révolution à la Première Guerre mondiale, red. P. Sénéchal, C. Barbillon, Paris site web de l'Institut National d'Histoire de l'Art, 2009, http:// www.inha.fr/fr/ressources/publications/dictionnaire-critique-des-historiens-de-1-art/ michiels-alfred.html [dostęp: 26.05.2015].

166 B. Kosmanowa, Biblioteki polskie w Wielkim Księstwie Poznańskim, Poznań 1992, s. 51-60. 
rza. Ich tytuły unaoczniają bardzo dobrą orientację właściciela Miłosławia $\mathrm{w}$ literaturze $\mathrm{z}$ zakresu, rodzącej się dopiero $\mathrm{w}$ pierwszej połowie XIX wieku, naukowej historii sztuki. Dzieła z biblioteki miłosławskiej uzupełniały teoretyczne i praktyczne podstawy licznych artystycznych pasji Seweryna Mielżyńskiego, a nierzadko bezpośrednio inspirowały jego podejście do historii europejskiego malarstwa.

\section{Bibliografia}

Źródła rękopiśmienne

Biblioteka Kórnicka PAN, Dział Rękopisów, sygn. BK 11272/3, BK 7472.

Biblioteka Jagiellońska, Dział Rękopisów, sygn. 6521 IV.

Archiwum Biblioteki Polskiej w Paryżu, sygn. akc. 2353, sygn. BPP 1569, BPP 1572.

Archiwum Muzeum Narodowego w Poznaniu, sygn. 1414/49, 1414/50.

Archiwum Państwowe w Poznaniu, Zespół Dokumenty i akta osób i rodzin, sygn. 157/1, 157/2.

Źródła drukowane

Skoraczewski F., Materyały do historyi Miłosławia, Poznań 1910.

Sprawozdanie z czynności Towarzystwa Przyjaciót Nauk Poznańskiego z roku 1882,

„Roczniki Towarzystwa Przyjaciół Nauk Poznańskiego" 1882, t. 12, s. 56.

Sprawozdania z czynności Towarzystwa Przyjaciót Nauk Poznańskiego od lipca 1866 do

kwietnia 1869, „Roczniki Towarzystwa Przyjaciół Nauk Poznańskiego”, t. 5, s. 366.

Sprawozdania z czynności Towarzystwa Przyjaciót Nauk Poznańskiego od kwietnia 1871 do grudnia 1872, „Roczniki Towarzystwa Przyjaciół Nauk Poznańskiego", t. 7, s. 253.

Wystawy Towarzystwa Sztuk Pięknych w Poznaniu (1837-1857). Materiaty źródłowe, oprac. M. Warkoczewska, Warszawa-Poznań 1991.

W.M., O wystawie obrazów w Poznaniu, „Przyjaciel Ludu”, nr 45, 10.05.1845, s. 357.

\section{Opracowania}

Ars una species mille. 150 dziet na 150-lecie Muzeum Narodowego w Poznaniu ze zbiorów Poznańskiego Towarzystwa Przyjaciót Nauk (katalog wystawy), red. D. Suchocka, Poznań 2007.

Bałus W., Nowy system wiedzy, w: J.J. Winckelmann, Dzieje sztuki starożytnej, przeł. T. Zatorski, oprac. W. Bałus, Kraków 2012, s. XIII-XXVII.

Candolle A. de, Rapport sur les travaux de la Société, "Mémoires de la Société de physique et d'histoire naturelle de Genève" 1862, t. 16, s. 452-456.

Cicha D., Seweryn Mielżyński i jego kolekcja, w: Zbiory Poznańskiego Towarzystwa Przyjaciót Nauk w Muzeum Narodowym w Poznaniu (katalog wystawy), Poznań 1982, s. 25-32. 
Dobrzyńska-Rybicka L., Biblioteka Towarzystwa Przyjaciót Nauk, w: Biblioteki wielkopolskie i pomorskie, red. S. Wierczyński, Poznań 1929, s. 39-72.

Gieszczyńska-Nowacka K., Kolekcjoner i artyści: Edward Rastawiecki wobec wspótczesnego środowiska artystycznego, w: Nowoczesność kolekcji, red. T.F. Rosset, A. Kluczewska-Wójcik, K. Lewandowska, Toruń 2010, s. 23-35.

Hellwig K., Von der Vita zur Künstlerbiographie, Oldenbourg 2005.

Jagielska-Burduk A., Szafrański W., Górska M.A., Wirtualna Galeria im. Mielżyńskich. Historia - idea - prawo, Poznań 2013.

Kieniewicz S., Łukaszewski Julian, w: Polski słownik biograficzny, t. 18, Kraków 1973, s. 551-552.

Kłudkiewicz K., Prowincjonalne centra - o kolekcjach sztuki w siedzibach arystokratycznych $w$ Wielkopolsce $w$ drugiej połowie XIX wieku, w: Centrum, prowincje, peryferia. Wzajemne relacje w dziejach sztuki, red. P. Gryglewski, K. Stefański, R. Wróbel, Łódź 2013, s. 301-322.

Kłudkiewicz K., Prywatne kolekcjonerstwo dzieł sztuki a kwestia ochrony dziedzictwa kulturowego - kiedyś $i$ dziś, w: Imponderabilia ochrony dziedzictwa kulturowego, red. S. Kowalska, Poznań-Kalisz 2015, s. 147-175.

Kłudkiewicz K., Wybór i konieczność. Kolekcje polskiej arystokracji w Wielkopolsce na przełomie XIX i XX wieku, praca doktorska napisana pod kierunkiem prof. dra hab. Tadeusza J. Żuchowskiego w Instytucie Historii Sztuki na Uniwersytecie im. Adama Mickiewicza w Poznaniu, maszynopis, Poznań 2013.

Koehlerówna A., Biblioteka Poznańskiego Towarzystwa Przyjaciół Nauk 1857-1957, „Roczniki Historyczne” 1957, t. 23, s. 381-430.

Kosmanowa B., Biblioteki polskie w Wielkim Księstwie Poznańskim, Poznań 1992.

Krawiec L., Lista członków Towarzystwa Demokratycznego Polskiego z lat 1832-1851, w: Materiały do biografii, genealogii $i$ heraldyki polskiej, t. 1, Buenos Aires-Paryż 1963.

Krzepela J., Rody ziem pruskich, Kraków 1927.

Krzywka Ł., Sztuk-mistrz polski Leon Kapliński (1826-1873), Wrocław 1994.

Langendorf J.J., Dufour Guillaume-Henri, w: Dictionnaire historique de la Suisse, http://www.hls-dhs-dss.ch/textes/f/F3862.php [dostęp: 22.02.2015].

Maës G., Dutch art collections and connoisseurship in the eighteenth century: the contributions of Dezallier d'Argenville and Descamps, „Similous: Netherlands Quarterly for the History of Art" 2009/2010, t. 34, nr 3/4, s. 226-238.

Malinowska J., Seweryn Mielżyński i jego galeria miłosławska, maszynopis, praca magisterska napisana pod kierunkiem prof. Krzysztofa Pomiana, Uniwersytet Mikołaja Kopernika, Wydział Nauk Historycznych, Katedra Sztuki i Kultury, Toruń 2002.

Marciniak R., Zbiory biblioteczne Poznańskiego Towarzystwa Przyjaciót Nauk, w: Zbiory Poznańskiego Towarzystwa Przyjaciót Nauk w Muzeum Narodowym w Poznaniu (katalog wystawy), Poznań 1982, s. 33-37.

Martin F.R., Michiels Alfred (1813-1892), w: Dictionnaire critique des historiens de l'art actifs en France de la Révolution à la Première Guerre mondiale, red. P. Sénéchal, C. Barbillon, Paris, site web de l'Institut National d'Histoire de l'Art, 2009, http://www.inha.fr/spip.php?article2331 [dostęp: 26.05.2015]. 
Michel P., Dezallier d'Argenville's "Abrégé de la vie des plus fameux peintres": a guide for contemporary collectors or a survey of the taste for paintings of the northern schools?, „Simiolus: Netherlands Quarterly for the History of Art” 2009/2010, t. 34, nr 3/4, s. 212-225.

Motty M., Przechadzki po mieście, t. 1, oprac. Z. Grot, Poznań 1999.

Murgia C., Gault de Saint-Germian, Pierre-Marie (1752-1842), w: Dictionnaire critique des historiens de l'art actifs en France de la Révolution à la Première Guerre mondiale, red. P. Sénéchal, C. Barbillon, Paris, site web de l'Institut National d'Histoire de l'Art, 2009, http://www.inha.fr/spip.php?article2331 [dostęp: 26.05.2015].

Orańska J., Seweryn Mielżyński jako artysta malarz (1804-1872) z okazji wystawy jego prac w galerji im. Mielżyńskich, „Dziennik Poznański”, nr 16, 20.01.1934, s. 2.

Polanowska J., Historiografia sztuki polskiej w latach 1832-1863, Warszawa 1995.

Płażewski I., Dzieje polskiej fotografii 1839-1939, Warszawa 2003.

Rogalanka A., Willa Mielżyńskich w Miłosławiu, „Studia i Materiały do dziejów Wielkopolski i Pomorza" 1962, t. 7, z. 1, s. 184-222.

Ryszkiewicz A., Zastugi Edwarda Rastawieckiego jako kolekcjonera i mecenasa, w: Mecenas, kolekcjoner, odbiorca, Warszawa 1984, s. 147-164.

Szlanta P., Narodziny nowoczesnej Szwajcarii, „Mówią wieki” 2008, nr 5, s. 25-28.

Trzeciakowski L., Posłowie polscy w Berlinie 1848-1928, Warszawa 2008.

Tyrowicz M., Towarzystwo Demokratyczne Polskie 1832-1863. Przywódcy i kadry członkowskie. Przewodnik biograficzny, Warszawa 1964.

Wojtkowski A., Historia Towarzystwa Przyjaciół Nauk w Poznaniu, Towarzystwo Przyjaciót Nauk w Poznaniu w latach 1857-1927, „,Roczniki PTPN”, t. 50, s. 281-286.

\section{KAMILA KŁUDKIEWICZ}

\section{The book collection of an art collector. A handful of comments about the library of Count Seweryn Mielżyński of Miłosław}

Aвstract. Count Seweryn Mielżyński belonged to the core group of preeminent art collectors in the nineteenth century Greater Poland. At his Miłosław palace he had his private book collection amounting to 5,000 volumes which, by his last will, he bequeathed to the library of the Poznan Society of Friends of Sciences. Following a query and extensive searches of the present book collection of the library it was possible to identify 287 titles, in 368 volumes, that were originally housed at Miłosław. The subject matter of the surviving books indicates that Mielżyński and his wife Franciszka were mostly interested in purchasing contemporary belles-lettres, therefore books that provided stimuli for entertainment, but also more serious literature with issues to be considered and one that provided food for thought. Additionally, a large 
group of books in the surviving book collection includes books on the fine arts, architecture and photography, which reflected the artistic interests of Seweryn Mielżyński and must have been useful in his painting and amateur photography endeavors. A separate group includes books that deal with historiography and the history of the arts, necessary for the owner to continue his collector's quest, and later used by him in developing a catalogue of his Western European paintings held at Miłosław.

Key words: Count Mielżyński's book collection, Miłosław library, library of the art. collector in the nineteenth century, book collections of the Mielżyński family, Polish private book collections in the nineteenth century. 